\title{
CENTRAL DO BRASIL: Uma perspectiva humanizada do nódulo central de transportes do Rio de Janeiro
}

\author{
Lua Bittencourt, Camila Medeiros, Marília Hildebrand, Clarisse Linke \\ Instituto Europeo di Design - Rio de Janeiro \\ Email: clarisse.linke@itdp.org
}

\section{RESUMO}

O presente trabalho vem com a intenção de demonstrar o estudo feito pelos colaboradores durante o Curso de Mobilidade Urbana Sustentável do IED - Instituto Europeu de Design em sua sede no Rio de Janeiro, durante o ano de 2016. O artigo pretende abordar o quadro atual da realidade do pedestre e usuário da Central do Brasil, o nó de transportes da cidade do Rio de Janeiro, assim como trazer as propostas elaboradas pelo grupo para a melhoria do espaço a nível do pedestre.

Palavras chave: Mobilidade Urbana, Caminhabilidade, Centralidade, Pedestre.

\section{ABSTRACT}

This paper intends to demonstrate the study done by the group during the Sustainable Urban Mobility Course of IED - European Design Institute at its headquarters in Rio de Janeiro, during the year 2016. The article intends to address the current framework of the reality of the pedestrian and user of Central do Brasil, the transport node of the city of Rio de Janeiro, as well as bringing the proposals made by the group to improve space at the pedestrian level.

Keywords: Urban mobility, Walkability, Centrality, Pedestrian. 


\title{
INTRODUÇÃO
}

A sustentabilidade se faz hoje ponto central nas discussões sobre o futuro das cidades, onde não se clama apenas pelo direito à cidade, mas também onde as reivindicações sociais e preocupações de estudiosos do espaço urbano estão centradas no direito às cidades sustentáveis. Etimologicamente, a palavra sustentabilidade vem de sustentare, que significa sustentar, apoiar e conservar. Temos hoje, portanto, a definição de que sustentabilidade é uma característica ou condição de um processo ou de um sistema que permite a sua permanência, em certo nível, por um determinado prazo, ou ainda, a característica associada a algo que se sustenta independentemente da ajuda de fatores externos. Ao se associar tal característica ao fator urbano e aplicá-la à uma cidade, espera-se um sistema urbano bem desenvolvido e resiliente ${ }^{1}$ mas, além de tudo, eficiente para quem nele habita.

A caminhabilidade ou, na origem, "walkability", por sua vez, é uma medida quantitativa e qualitativa que indica quão amigável uma área é para caminhadas e uso do espaço público. Alguns dos fatores que influenciam em sua definição são a qualidade de caminhos e calçadas, condições de trânsito, padrões de uso da terra, a acessibilidade e segurança, entre outros. Por tudo o que representa, a caminhabilidade é um conceito fundamental em uma concepção urbana sustentável.

Ao longo do tempo e com o desenvolvimento das cidades, os centros urbanos, especialmente no Brasil, cenário base das nossas observações e do estudo deste trabalho, foram se expandindo. Consequentemente, grande parte das cidades foram se espraiando, levando as moradias para cada vez mais longe dos centros comerciais consolidados e originando assim, por vezes, novas centralidades. O IBGE constatou (2015:304):

\begin{abstract}
"As políticas predominantes no domínio dos transportes urbanos priorizaram o desenvolvimento da infraestrutura viária, em grande parte estimuladas pelo forte crescimento das frotas de automóvéis - e mais recentemente também das motos. No espaço de somente 12 anos, o índice referente ao número de habitantes por automóvel no Brasil reduzia-se de 8,6 para 5,1. Ou seja, uma redução da ordem de $41 \%$, aproximadamente, do que decorreu forte agravamento nas condições de congestionamento observadas especialmente nos centros de grande porte e aglomerações urbanas e mesmo em muitos dos centros urbanos de médio porte."
\end{abstract}

Com isso, vemos hoje uma realidade na qual a maior parte das pessoas das médias e grandes cidades opta pelo carro, devido às longas distâncias, o que leva ao inchaço do sistema viário e provoca, além de trânsito, diversos outros problemas para a dinâmica urbana, como a diminuição de pedestres nas ruas. A rua, por sua vez, tem diversos fins além do tráfego de veículos, da mesma forma que as calçadas têm outros papéis além de acolher pedestres. Assim, as ruas e calçadas de uma cidade são seus órgãos mais vitais, uma vez que é por meio da grade de ruas que realizamos nosso percurso, nosso passeio e nossas trocas na cidade. Vemos essa questão bem explicitada por GHEL (2013:19):

“(...)Gradualmente, calçadas estreitas foram ficando pontilhadas de placas de sinalização, parquímetros, postes, luminárias de rua e outros obstáculos colocados de modo a "não ficar no caminho". Entenda-se, "no caminho do tráfego motorizado", que é o que importa. Aos obstáculos físicos, juntem-se as frequentes interrupções no ritmo da caminhada causadas pelas longas paradas em semáforos, difíceis cruzamentos de ruas, passagens elevadas para pedestres e túneis subterrâneos desertos. Todos esses exemplos de organização da cidade têm um objetivo: proporcionar mais espaço e melhores condições para os carros. Como consequência, caminhar ficou mais difícil e menos atrativo."

Richard Rogers (2001), afirma que o tráfego urbano acaba por destruir o sentido de comunidade de uma rua. Na busca por um modelo sustentável de cidade, ele defende o investimento na "ideia de 'cidade compacta' - uma cidade densa e socialmente diversificada onde as atividades econômicas e sociais se sobreponham e onde as comunidades sejam concentradas em torno das unidades de vizinhança". Este conceito, não exclusivamente defendido por Rogers, difere-se do modelo atual predominante em muitos países, a cidade dividida em zonas por funções (residência afastada, comercial e institucional ao centro). O planejamento por zonas trouxe o que hoje mostra ser uma das

${ }^{1}$ Do dicionário: s.f.: capacidade de se recobrar facilmente ou se adaptar às mudanças. 
maiores questões das grandes cidades. Quanto maior a cidade, maiores tendem ser as distâncias entre moradia e trabalho (ou vice-versa), maiores os deslocamentos e mais automóveis passam a transitar nas ruas. Jane Jacobs (2011) já questionava, em 'Morte e vida das grandes cidades'(JACOBS, 2000):

“É questionável que parcela da destruição provocada pelos automóveis nas cidades deve-se realmente às necessidades de transporte e trânsito e que parcela deve-se ao puro descaso com outras necessidades, funções e usos urbanos. (...) aquele que se desespera com a guerra entre esses aliados potenciais, automóveis e cidades, tende a descrever o impasse como uma guerra entre automóveis e pedestres. "

O dito modelo urbano, adotado principalmente na época do fordismo ${ }^{2}$, implicou em uma ocupação urbana extensiva que é exigente em mobilidade, uma vez que gera deslocamentos cada vez mais intensos, mais longos, diversificados e aleatórios, o que repercute no consumo de combustíveis e no aumento da poluição (ruído, emissões atmosféricas poluentes) e do congestionamento.

Veremos, ao longo deste trabalho, que a concepção do grande nó modal ${ }^{3}$ do Rio de Janeiro se deu, não só estrategicamente para a construção da malha de transportes, mas também devido às diferentes etapas de crescimento da cidade e à importância do local onde está situado. Assume-se desde o início também que um nó da rede de transportes é muito mais do que apenas um nó em sentido estrito, constituindo também um verdadeiro lugar da região, identificável e com uma certa dimensão e estrutura urbana e que, para a avaliação do espaço, deve-se olhar tanto no que diz respeito à sua acessibilidade multimodal como também à sua importância e capacidade de atração urbanística e funcional.

Tendo em conta estas últimas afirmações, chegou-se à hipótese de que a Central do Brasil, nó modal da cidade do Rio de Janeiro, apesar de ser um importante ponto focal de transportes e área do centro da cidade, não apresenta qualidade no espaço oferecido para os seus usuários: os pedestres. Para melhor demostrar o estudo feito, o texto está dividido em quatro partes, além da introdução e das considerações finais. A primeira delas traz um breve histórico do crescimento da cidade, a fim de se ilustrar a constituição do espaço e o que levou à dita importância do local para a cidade. Na segunda parte, se desenrolará a apresentação do recorte da área de estudo e os elementos nela presentes, tanto em seu entorno, partes do conjunto, quanto os modais que se cruzam e compõe o nó de transportes em si. A terceira parte, o "Diagnóstico", tece, como o nome mesmo indica, a construção da análise e diagnóstico do espaço, pensando na escala do pedestre, o qual será apresentado aqui como o usuário fundamental dos modais e da cidade, do lugar por assim apresentado. A quarta e última etapa do texto vem para expor as propostas elaboradas para intervenções no espaço da Central do Brasil provindas dos resultados da análise do espaço cruzadas com os princípios da caminhabilidade.

\section{BREVE HISTÓRICO E ELEMENTOS DA ÁREA ESTUDADA}

${ }^{2}$ Como definição resumida, têm-se para fordismo um sistema de produção, criado pelo empresário norte-americano Henry Ford, cuja principal característica é a fabricação em massa. Ford criou então este sistema em 1914 para sua indústria de automóveis, projetando um sistema baseado numa linha de montagem. $\mathrm{O}$ acesso à tecnologia tornou possível maiores deslocamentos dos indivíduos, permitindo assim que fossem morar cada vez mais longe de seus trabalhos.

${ }^{3}$ Têm-se, neste trabalho, o conceito de nó modal como o principal encontro de modais, um nó na malha de transportes de uma cidade. 
Para falarmos sobre a Central do Brasil e a área que compõe o dito nódulo de transportes, é preciso ilustrar, mesmo que brevemente, a concepção do espaço em questão e a sua importância na construção e no desenvolvimento da cidade do Rio de Janeiro.

No século XVIII, auge da produção do ouro e de diamantes, o porto do Rio de Janeiro tornou-se o principal centro exportador dos minerais de Minas Gerais para Portugal, assim como o relevante espaço de entrada para escravos originários da África e de produtos manufaturados europeus. Esse papel estratégico do ciclo do ouro proporcionou um rápido desenvolvimento à cidade que, já a partir de 1763, tornou-se a sede do Governo Geral. Em 1808, para fugir da invasão Napoleônica, a Família Real Portuguesa transferiu-se para o Brasil, o que transformou o Rio de Janeiro em sede do Governo Português. (OBSERVATÓRIO DAS METRÓPOLES, 2015) Esse fato fez com que o Rio de Janeiro se desenvolvesse rapidamente e, já nas proximidades da Proclamação da República e com a queda do trabalho escravo, a cidade passou por uma época de crescimento desordenado. Como já não comportava a população que duplicou entre os anos de 1872 e 1890 (IBGE, 2011), a cidade passou por uma crise habitacional, vivenciando então um movimento de favelização da sua área central. Este primeiro momento marca então a abertura de vias e a guinada para as zonas norte e sul da cidade, o que gerou o aumento da ocupação do território e enviou a população mais pobre para a zona portuária da cidade.

As primeiras décadas do século $X X$ trouxeram modernidade para a cidade e, com ela, novas perspectivas se abriram para o planejamento urbano, tais como a política higienista de Pereira Passos e a visita e consequente plano urbanístico de Alfred Agache. Concluído em 1930, o Plano Agache introduziu no cenário nacional algumas questões típicas da cidade industrial, tais como o planejamento do transporte de massas e do abastecimento de águas, a habitação operária e o crescimento das favelas e, além disso, com discussões emergentes que iam desde a necessidade de um zoneamento para a cidade até a delimitação de áreas verdes, ultrapassou os limites do Academicismo das intervenções predecessoras de Pereira Passos e Paulo de Frontin. (Governo do Rio de Janeiro, 2010)

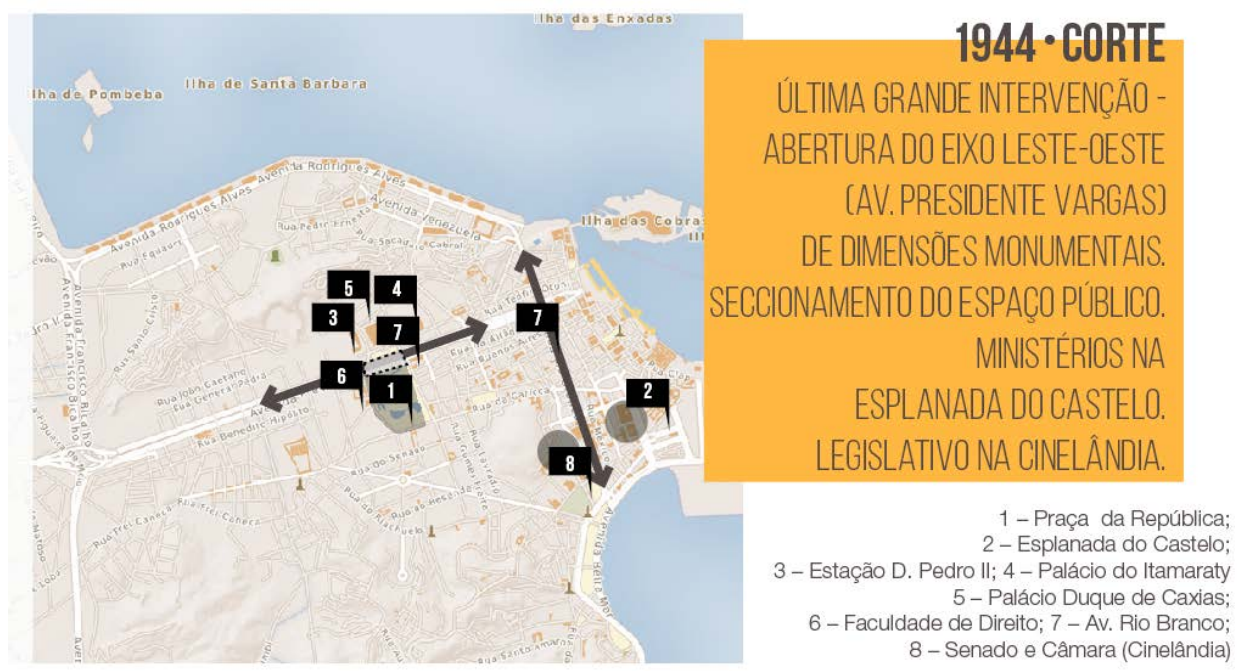

Imagem 1 - Mapa da região central do Rio de Janeiro em 1944

Elaboração própria com base cartográfica do sítio eletrônico http://imaginerio.org

O momento seguinte retratou o início de um movimento que marcou não só a forma do crescimento do Rio de Janeiro, mas também do país. Foi o movimento modernista que, associado ao fordismo, impulsionou o planejamento urbano na direção da monumentalidade e dos espaços amplos e longínquos. James Holston (1993) trouxe, em "A Cidade modernista", uma pintura da ideologia que envolvia essas novas premissas urbanísticas adotadas pelo país:

"O ponto chave do internacionalismo modernista era o de que a teoria e a tecnologia da cidade modernista ofereciam um meio já pronto de salvar o mundo subdesenvolvido do caos e das 
iniqüidades da revolução industrial européia. A salvação exigia que se implementasse uma política nacional de desenvolvimento urbano no qual as cidades modernistas serviriam como modelos e os nódulos do desenvolvimento regional. A construção de cidades novas, sobretudo capitais iria estimular a tecnologia, estabelecer redes de comunicação, integrar regiões vastas, atrasadas e repletas de recursos inexplorados, além de organizar coletivamente as relações sociais de modo a maximizar os benefícios potenciais daquela máquina."

Foi nesse contexto que a Avenida Presidente Vargas foi inaugurada e é, ainda hoje, uma das principais avenidas do centro da cidade e marca a ligação, mesmo que indiretamente, do Centro com as Zonas Norte e Oeste. A inauguração desta avenida pôs-se especialmente notável para este estudo devido à sua localização: é nela que se encontra a edificação da Central do Brasil.

As décadas seguintes foram pautadas em torno da exaltação ao automóvel. Enquanto era construída uma cidade modernista para ser a nova Capital Federal (Brasília), o Rio de Janeiro continuava a se expandir para a Zona Oeste e grandes obras urbanísticas como o Aterro do Flamengo e a Perimetral (avenida de ligação do aeroporto com Niterói, Zona Norte e Zona Sul) foram estrelas desta "Era Modernista" e do planejamento voltado para as longas distâncias.

Já os anos 2000 foram marcados por grandes eventos que ocorreram na cidade (Jogos Panamericanos em 2007, Copa do Mundo em 2014 e Olimpíadas em 2016) e trouxeram, devido à sua visibilidade, novos investimentos e pensamentos sobre o espaço público do Centro. Um desses pensamentos levado à prática foi a Operação Urbana do Porto Maravilha, que acaba de ser finalizada (2016) e engloba o remodelamento urbano, a revitalização de edifícios históricos e a melhoria e implantação de transportes e serviços na área portuária do Rio de Janeiro.

Tais melhorias e implantações, apesar de não passarem especificamente pela área abordada por este estudo (como visto na imagem a seguir), acabaram por interferir na dinâmica do espaço, uma vez que foram inseridos mais dois modais de transporte e, com a volta do foco para o centro e para a zona portuária, mais pessoas passaram e passarão a se deslocar para a região, aumentando ainda mais o fluxo de transeuntes e utilizadores do espaço que já se encontra saturado.

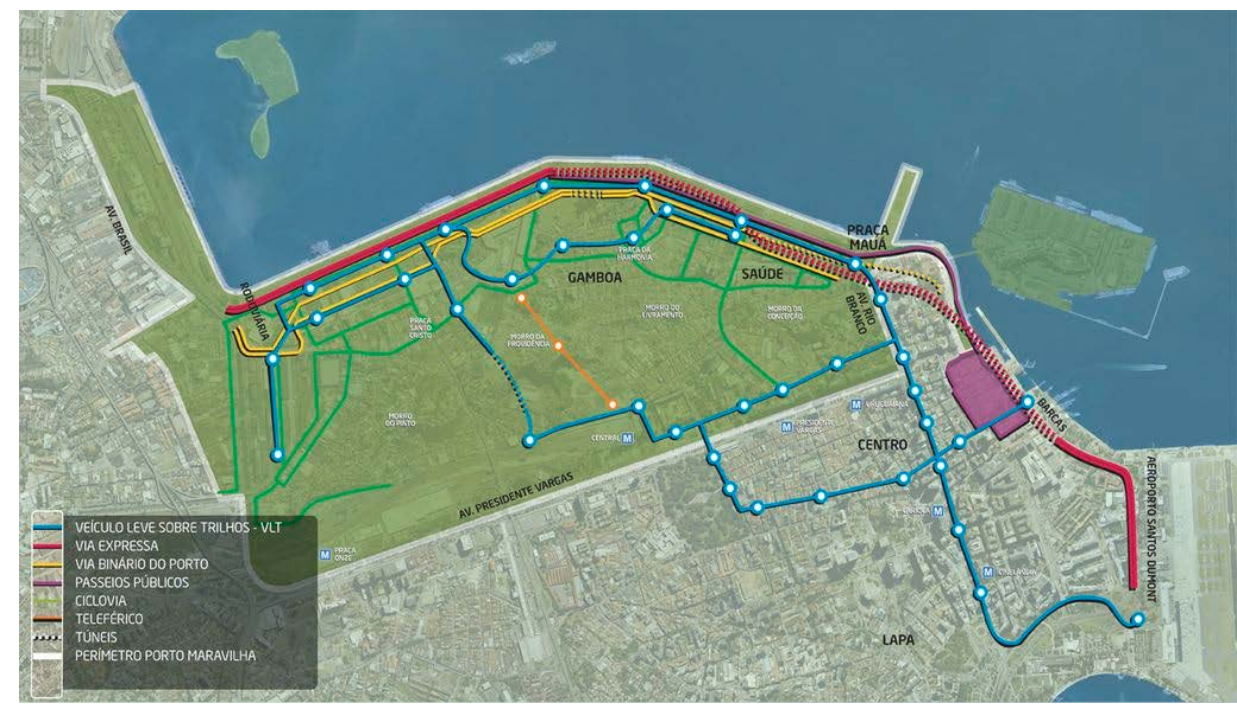

Imagem 2 - Mapa do novo sistema de transporte da Operação Urbana Porto Maravilha

Retirado da plataforma eletrônica $h$ ttp://www.portomaravilha.com.br/noticiasdetalhe/4126

Como mostrado, a Central do Brasil e a região que compõe o seu entorno imediato constituem atualmente o mais importante nó de transportes da cidade do Rio de Janeiro. Além da presença de diferentes modais que conectam praticamente toda a cidade e o consequente fluxo intenso de pessoas, sua importância está também relacionada às instituições e lugares históricos que compõem este cenário. 
O edifício da Central do Brasil recebe as cinco linhas de trens metropolitanos que fazem a ligação com as zonas norte e oeste da cidade e com os municípios da Baixada Fluminense, além da estação de metrô que faz a ligação entre duas das três linhas da cidade, o que gera um movimento de 600 mil pessoas por dia apenas dentro do edifício da Central. Na área adjacente ao edifício ainda encontramse dois terminais de ônibus municipais e intermunicipais, uma estação de teleférico que conecta a 'cidade baixa' ao Morro da Providência e a importante Avenida Presidente Vargas, como já apresentado, responsável também pela conexão rodoviária, do centro com as zonas norte e oeste. Com os projetos da operação urbana 'Porto Maravilha', pontos de VLT (Veículo Leve Sobre Trilhos) que fazem parte de um circuito que conecta o centro à zona portuária e do novo BRT serão também implantados nessa área, reafirmando seu protagonismo na dinâmica urbana do Rio de Janeiro.

Tal protagonismo é, entretanto, anterior a inauguração da Estrada de Ferro D. Pedro II (atual Central do Brasil) em 1854, e inicia-se com a presença do Campo de Santana, que concentrou, ao longo do tempo, importantes marcos e edificações de diferentes esferas do governo imperial ao seu redor e mesmo em seu interior, firmando-se à época como principal centro da administração pública do Rio de Janeiro. Encontra-se nas imediações o conhecido Palácio Duque de Caxias, sede do Comando Militar do Leste. Ao sul do Campo de Santana, está ainda situada a sede do Quartel Central do Corpo de Bombeiros do Rio de Janeiro. Do século XIX, data também a construção da casa de Marechal Deodoro da Fonseca, atual Museu do Exército situado no lado oriental do Campo.

Após a proclamação da República, o Campo de Santana não perdeu subitamente a condição de centralidade, devido à presença destes marcos históricos edificados. De certo modo, essa condição foi inclusive reforçada pelo Governo Provisório quando adquiriu o palácio construído para o Conde de Itamaraty para ser a sede da Presidência da República de 1889 a 1897.

Nas proximidades da área de estudo encontra-se também o famoso centro comercial SAARA (Sociedade de Amigos e Adjacências da Rua da Alfândega) que desde a sua criação em 1862, representa um importante ponto de atração de pessoas durante o horário comercial. Além dos já apresentados, outros equipamentos surgiram na região ao longo do tempo e contribuem para o grande fluxo de pessoas diariamente, como a Biblioteca Parque, A Faculdade de Direito da UFRJ e o Hospital Souza Aguiar.

Por todo o exposto, é possível entender a importância da área que envolve a Central do Brasil não só por estar no centro geográfico da cidade, mas também por configurar, por si só, uma centralidade no âmbito em que representa, além do lugar físico onde se situam serviços, uma zona de influência concentradora dos usuários destes serviços e dos fluxos de relações, que ligam os usuários a essa centralidade (Kneib, 2012 apud Rochefort ,1998). É esse caráter convergente que a faz provedora da concentração de atividades, linhas e terminais de transporte. Assim, interfere significativamente na mobilidade da cidade do Rio de Janeiro com a dita grande oferta de modais de transporte associada à presença de equipamentos públicos e áreas comerciais relevantes para o dia-a-dia do carioca, podendo ser considerada como um "Polo Gerador de Viagem" $(P G V)^{4}$, conceito muito utilizado na literatura para referir-se a um empreendimento de grande porte, mas que aqui pode ser entendido como um conjunto de atividades que atraem viagens, sejam elas de que tipo forem.

É, com isso se chega ao potencial da dita área como objeto para este estudo, uma vez que representa um espaço de grande concentração de pessoas, seja por seu caráter de passagem e distribuidor de fluxos, seja por seu poder de atração, mas que não está pensado e preparado para receber o seu principal usuário, o pedestre. Tal afirmação pode ser constata no diagnóstico a seguir.

${ }^{4}$ Polos Geradores de Viagem: originalmente denominados Polos Geradores de Tráfego (PGT), são "locais ou empreendimentos de distintas naturezas que tem em comum o desenvolvimento de atividades em porte e escala capazes de exercer grande atratividade sobre a população, produzir um contingente significativo de viagens, necessitar de grandes espaços para estacionamento, cargas e descargas de bens, e embarque e desembarque de pessoas" (Santos \& Freitas apud Rede PGV, 2014) 

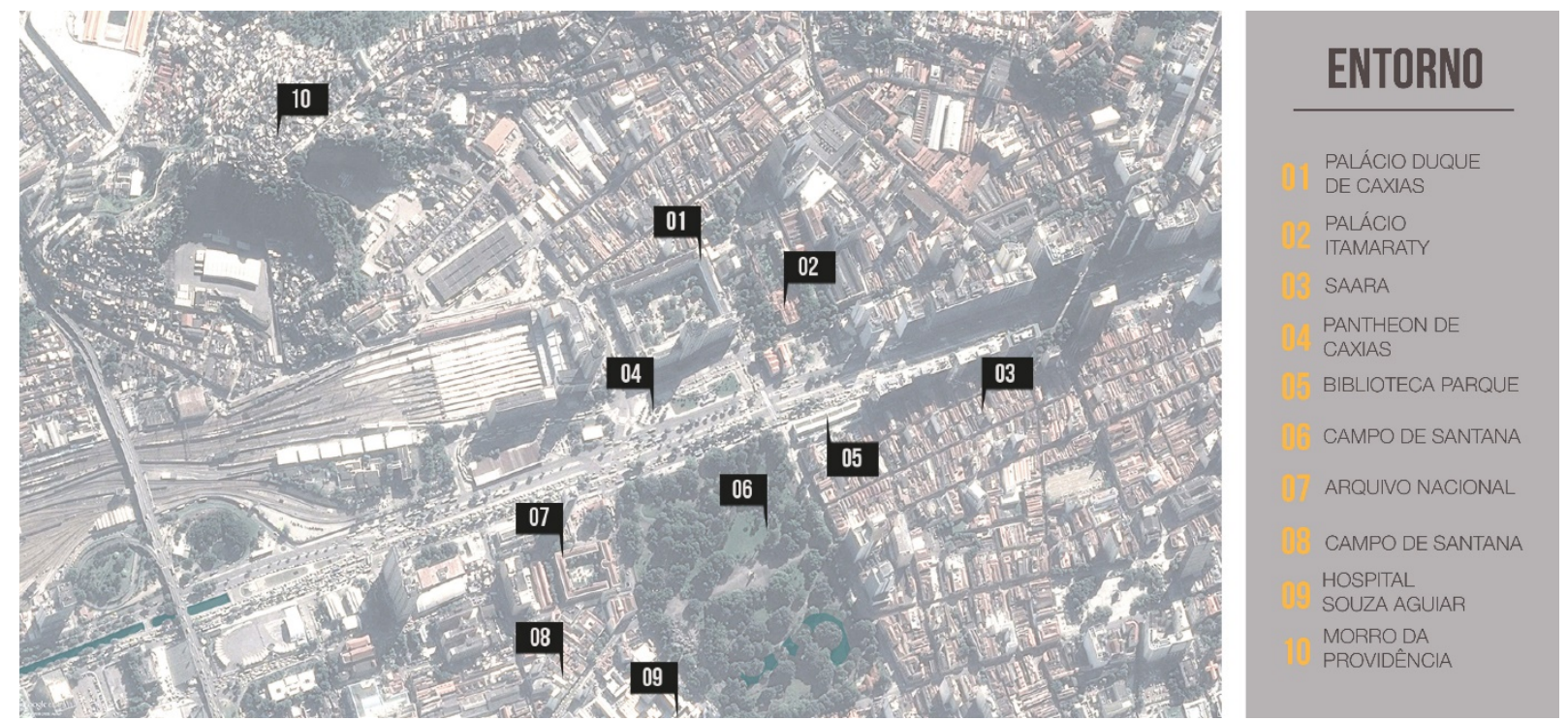

Imagem 3 - Mapa do entorno da estação Central do Brasil

Elaboração própria com base cartográfica do sítio eletrônico http://googlemaps.com

\section{DIAGNÓSTICO}

Com a então apresentação do histórico da evolução do Centro do Rio de Janeiro, se nota, sobretudo em anos mais recentes, um crescimento explosivo no número de automóveis e motocicletas nas ruas da cidade. Apesar de apresentar crescimento menor do que as médias nacional e metropolitana, o município do Rio de Janeiro registrou um aumento considerável, já que a frota teve um crescimento de $73,1 \%$, ou seja, mais de 1,2 milhão de automóveis em termos absolutos. Além disso, ao contrário da maioria das regiões metropolitanas, na Região Metropolitana do Rio de Janeiro (RMRJ), as variações anuais continuam crescentes desde 2003. Isso significa que, apesar de ser a região em que menos cresce a população, é uma das poucas que mantém uma tendência ascendente no ritmo do crescimento de veículos (OBSERVATÓRIO DAS METRÓPOLES, 2013).

Em paradoxo, apesar desta crescente motorização, tem sido visto o aumento no número de pessoas que levam mais tempo no trajeto entre seus locais de residência (mais de 1 hora), como no tempo médio de deslocamento na RMRJ. Nesse contexto, se em décadas anteriores a posse do automóvel atendeu a um aspecto econômico-ideológico, representado pelo modelo rodoviarista, e, ao mesmo tempo, propiciou o aumento da velocidade de deslocamento da classe média, já que este, o automóvel, se desloca a uma velocidade bem superior à do ônibus, atualmente verifica-se o esgotamento dessa verdade impressa em grandes engarrafamentos e no dito aumento do tempo dos deslocamentos. Vemos no gráfico a seguir o tempo médio de deslocamento casa-trabalho por municípios: 

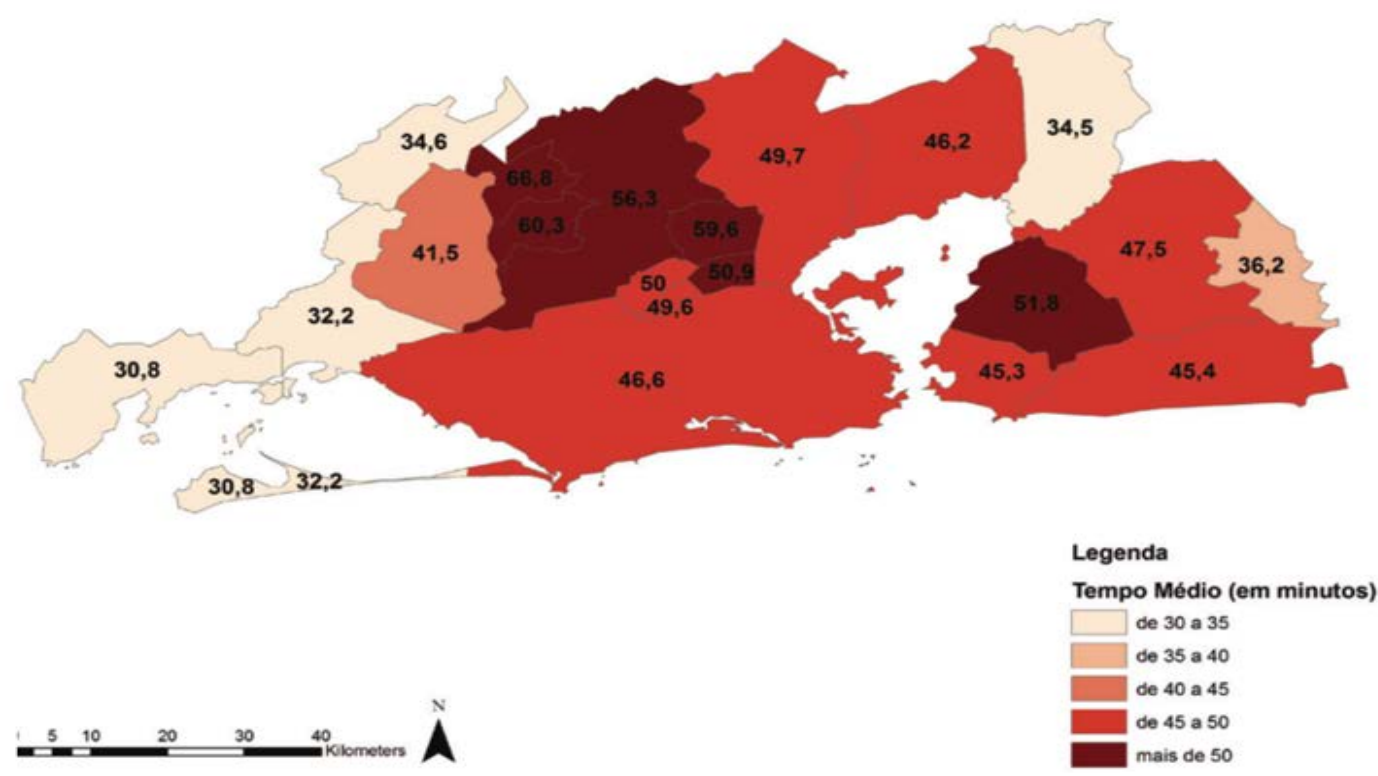

Imagem 4 - Mapa de tempo médio de deslocamento casa-trabalho na RMRJ (IBGE, CENSO 2010)

A mobilidade urbana é um atributo das cidades e se refere à facilidade de deslocamento de pessoas e bens no espaço urbano (MCIDADES, 2007). Segundo Duarte (2007), a mobilidade urbana no Brasil segue centrada na valorização de um único meio de transporte: o automóvel, o qual já vem mostrando diversos efeitos caóticos para as cidades no que se refere tanto à segurança quanto à qualidade de vida. Esse modo de transporte é valorizado sobre os não motorizados e motorizados coletivos pela sua relação distância/tempo que, em muitos casos, é bastante reduzida.

Como dito anteriormente, a área em que se encontra a edificação da Central do Brasil representa grande significado para a identidade do Rio de Janeiro e do Brasil, mas, no entanto, ela foi sendo transformada numa espécie de passagem, de não lugar, sem falar em uma certa degradação das condições de segurança. Assim, entre o dito Polo Gerador de Viagem e um mero local de passagem, constatamos que a Central acaba por se mostrar esquecida e perdida na centralidade que ela própria representa.

Para início de um diagnóstico mais preciso da área, primeiro foi feito o levantamento dos modais de transporte que se encontram no entorno da Central e, na sequência, uma análise dos principais fluxos de pedestres que chegam, saem e passam pela área em diferentes horários e dias da semana foi moldada a partir da observação direta em pontos diversos da área estudada.

\section{MODAIS DE TRANSPORTE E PERCURSOS}

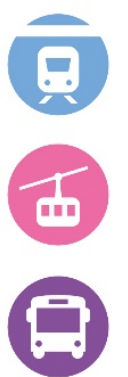

ESTAÇÕES DE METRÔ

ESTAÇÕES E TRAJETO DO TELEFÉRICO

TERMINAIS, PONTOS E TRAJETOS DE ÔNIBUS
ESTAÇÕES DE BICICLETA COMPARTILHADA, ADOÇÃO DE CICLOVIAS IMPLANTADAS E PROJETO CICLORROTAS

ESTAÇÃO DE TREM (CENTRAL DO BRASIL)

PONTOS E TRAJETOS DO VLT

Imagem 5 - Legenda de Modais para imagens 6, 7, 8, 9, 10 e 11 


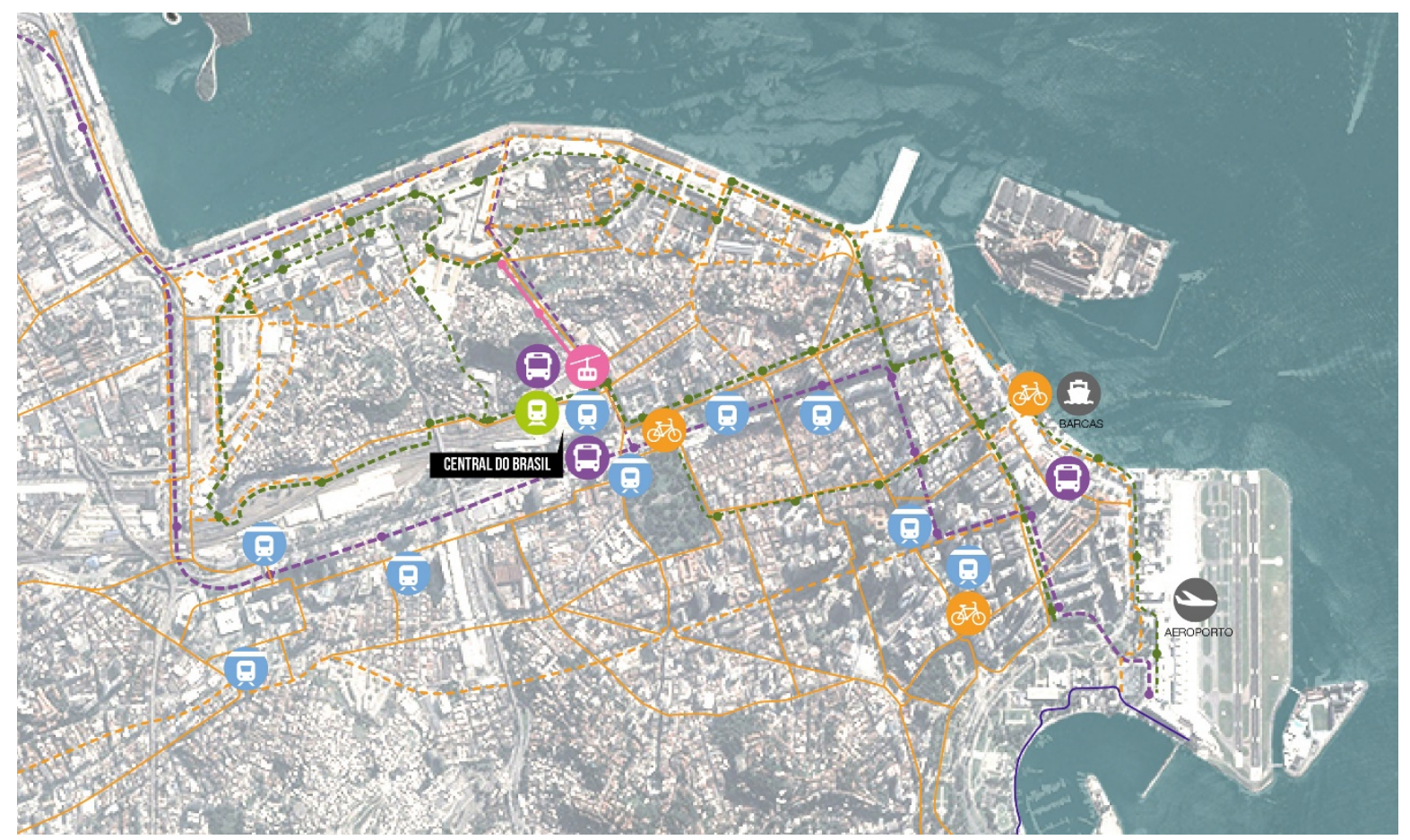

Imagem 6 - Mapa de oferta de transporte público na região central do Rio de Janeiro Elaboração própria com base cartográfica do sítio eletrônico http://googlemaps.com

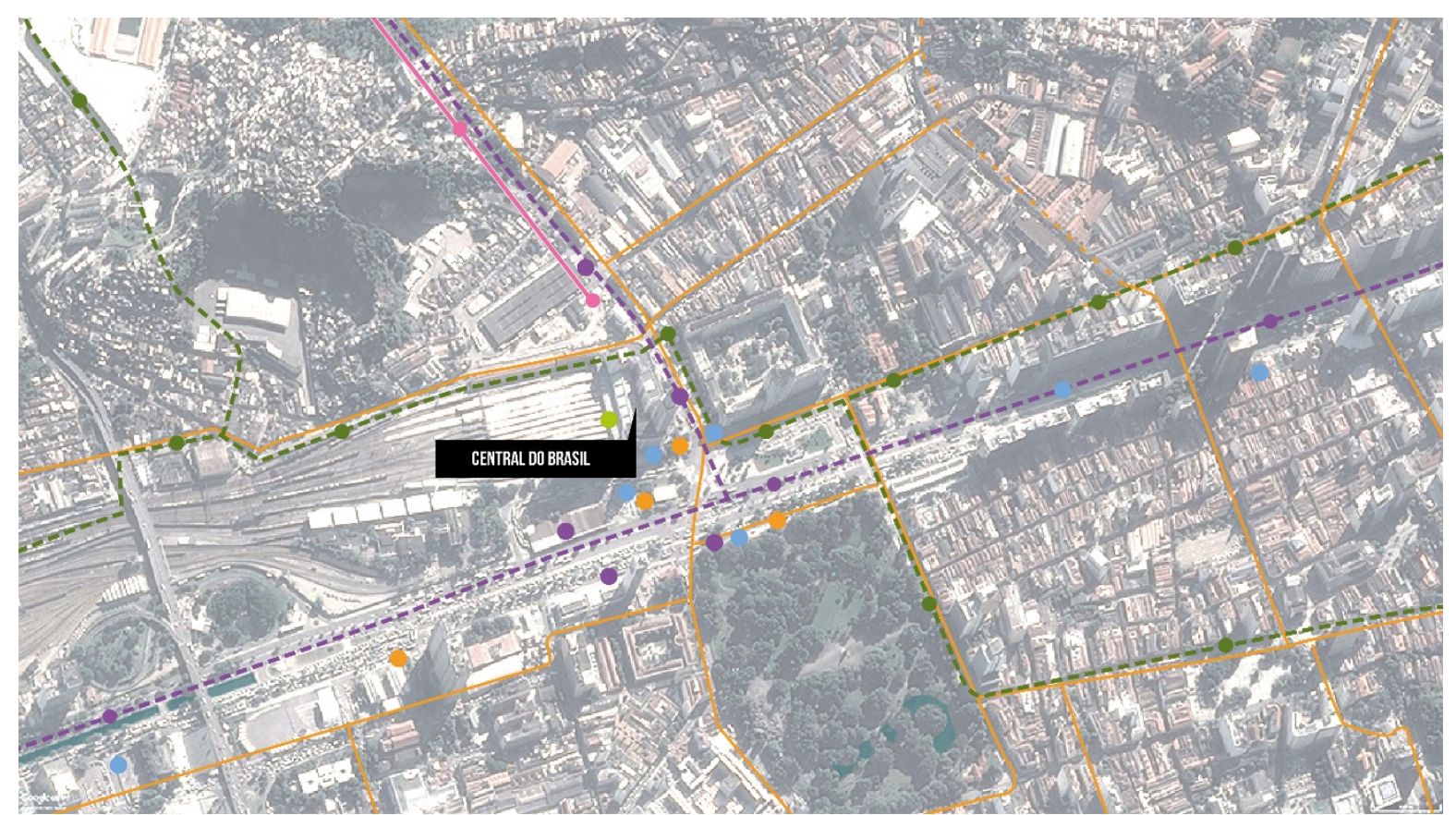

Imagem 7 - Mapa de oferta de modais de transporte no entorno da estação Central do Brasil

Elaboração própria com base cartográfica do sítio eletrônico http://googlemaps.com 


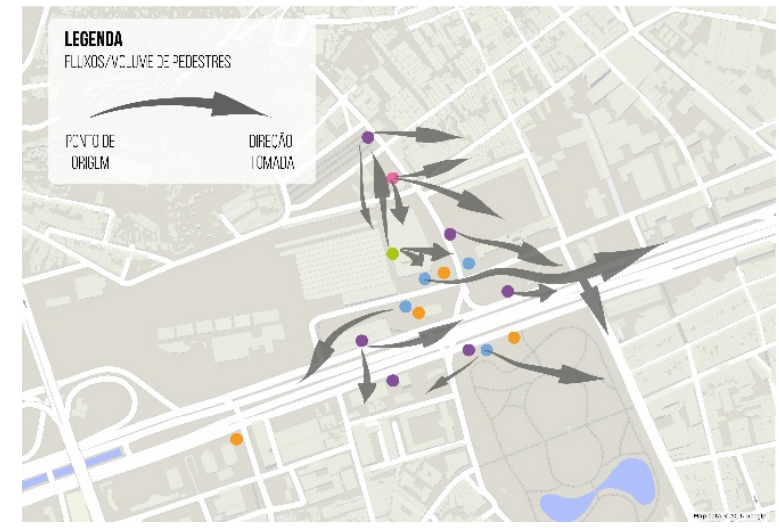

Imagem 8 - Fluxos entre segunda e sexta-feira no período da manhã

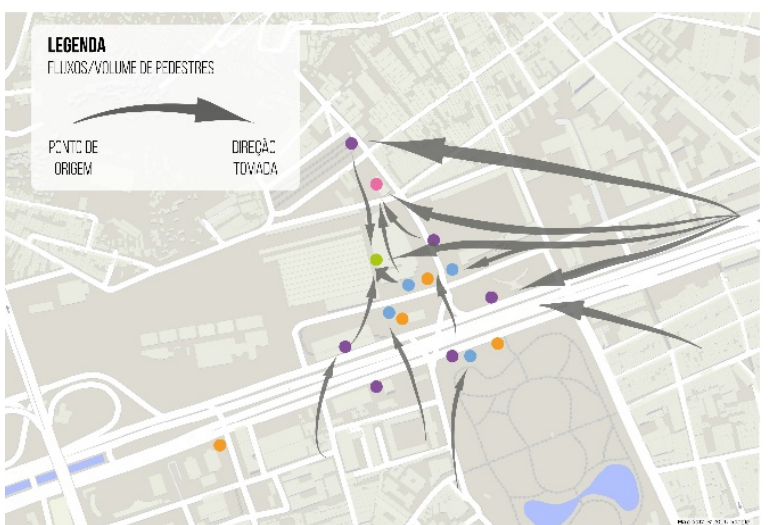

Imagem 10 - Fluxos entre segunda e sexta-feira no fim de tarde

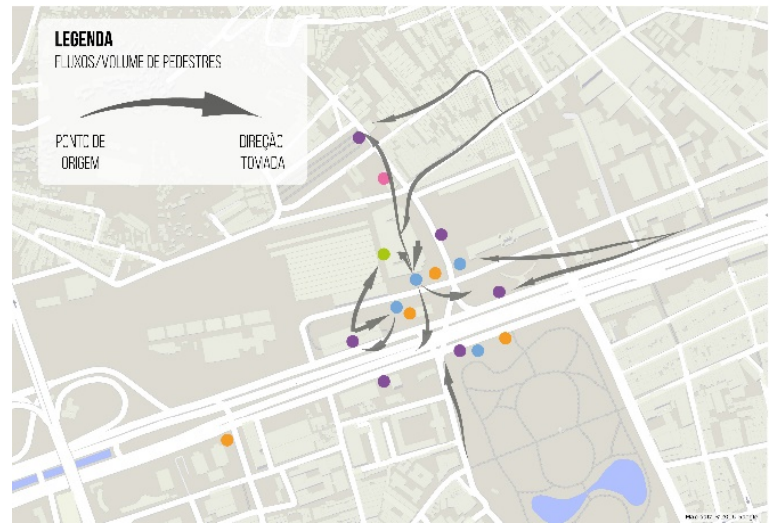

Imagem 9 - Fluxos entre segunda e sexta-feira no início da tarde

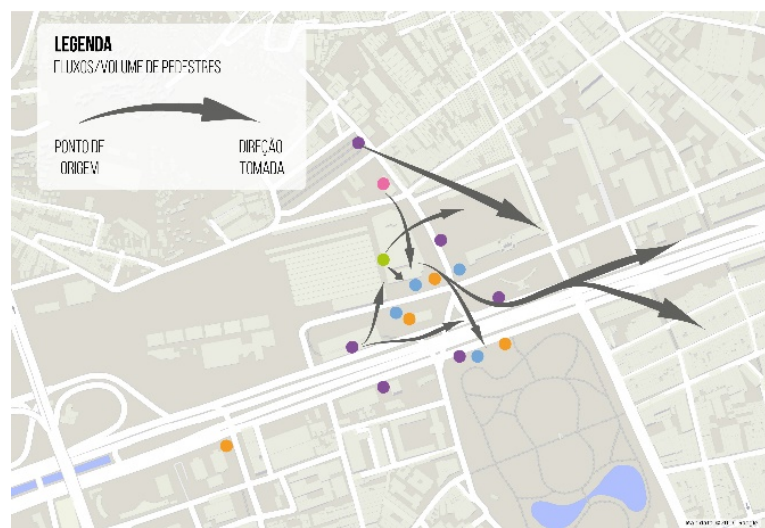

Imagem 11 - Fluxos sábado durante o dia

Estudos de fluxos de pedestre entre modais de transporte

Elaboração própria com base cartográfica do sítio eletrônico http://googlemaps.com

A partir desses dois levantamentos, optou-se por cruzar os três fluxos de maior conflito, posto que acabam por ocupar o mesmo espaço urbano: os automóveis, os ônibus e os pedestres.

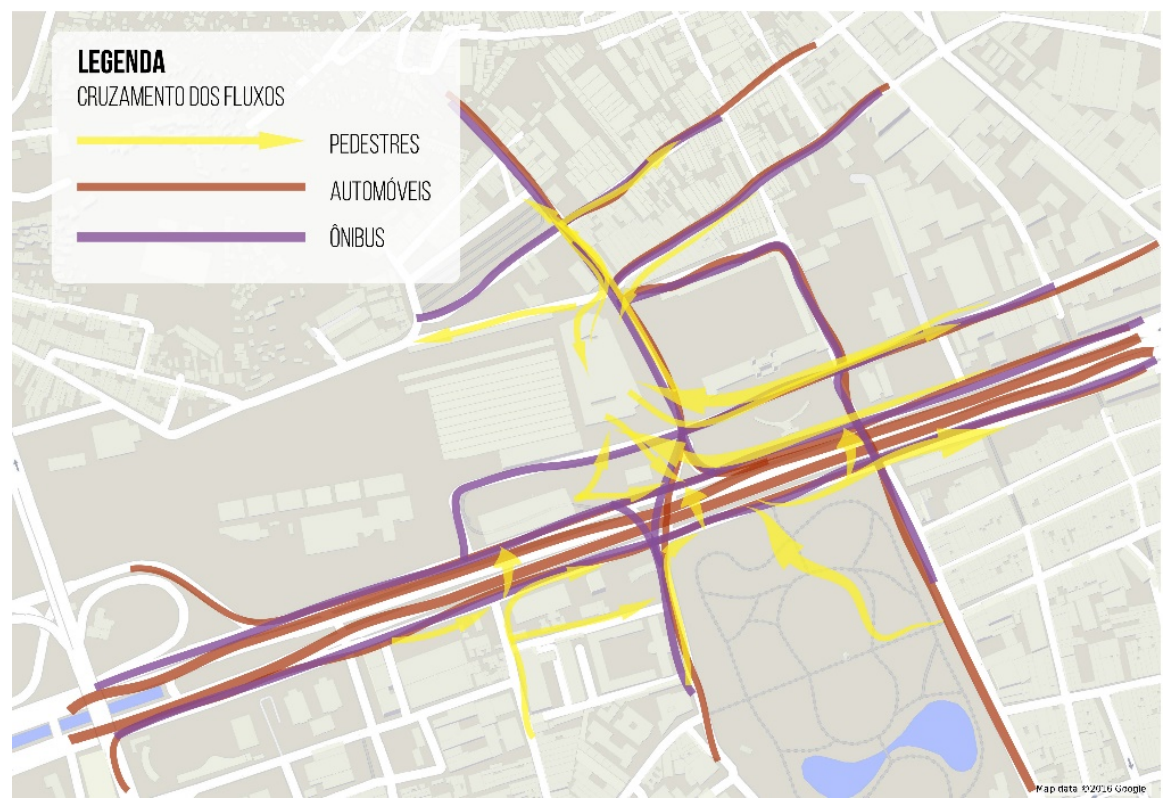

Imagem 12 - Cruzamento dos fluxos de pedestres, ônibus e automóveis

Elaboração própria com base cartográfica do sítio eletrônico http://googlemaps.com 
Ao analisar esses fluxos é possível perceber os conflitos gerados e suas consequências no que diz respeito à segurança viária, como apresentado nos gráficos e mapas a seguir:

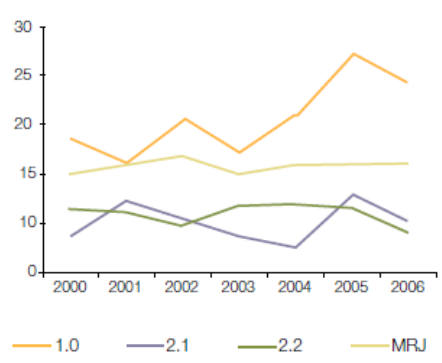

TAXA DE MORTALIDADE POR ACIDENTES DE TRANSPORTE, RESIDENTES NAS AP 1.0,2.1E 2.2 DE CIDADE DO RIO DE JANERO - 2000 A 2006
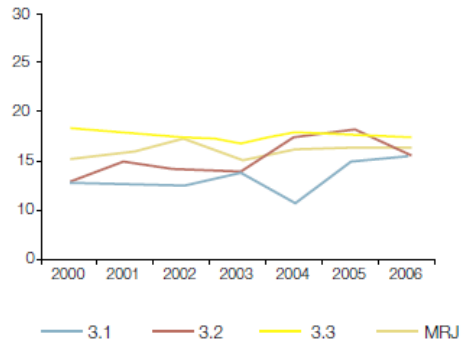

TAXA DE MORTALIDADE POR ACIDENTES DE TRANSPORTE, RESIDENTES NAS AP $3.1,3.2$ E 3.3 DA CIDADE DO RIO DE JANERO - २००० A २००६
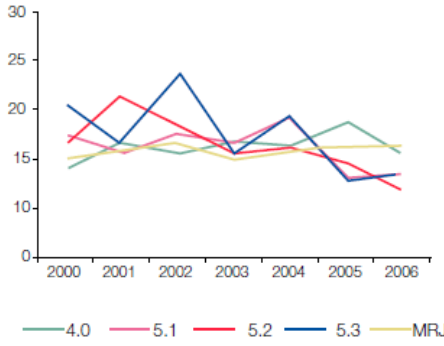

TAXA DE MORTALIDADE POR ACIDENTES DE

TRANSPORTE, RESIDENTES NAS AP 4.0,5.1,5.2E 5.3 DA CIDADE DO RIO DE JANERR - २००० A २००६

Imagem 13 - Gráficos indicativos de taxas de mortalidade por acidentes (Sistema de Informações sobre Mortalidade - GIE/SVS/SUBASS/SMS-RJ e Estimativa Populacional Instituto Pereira Passos IPP, 2016)
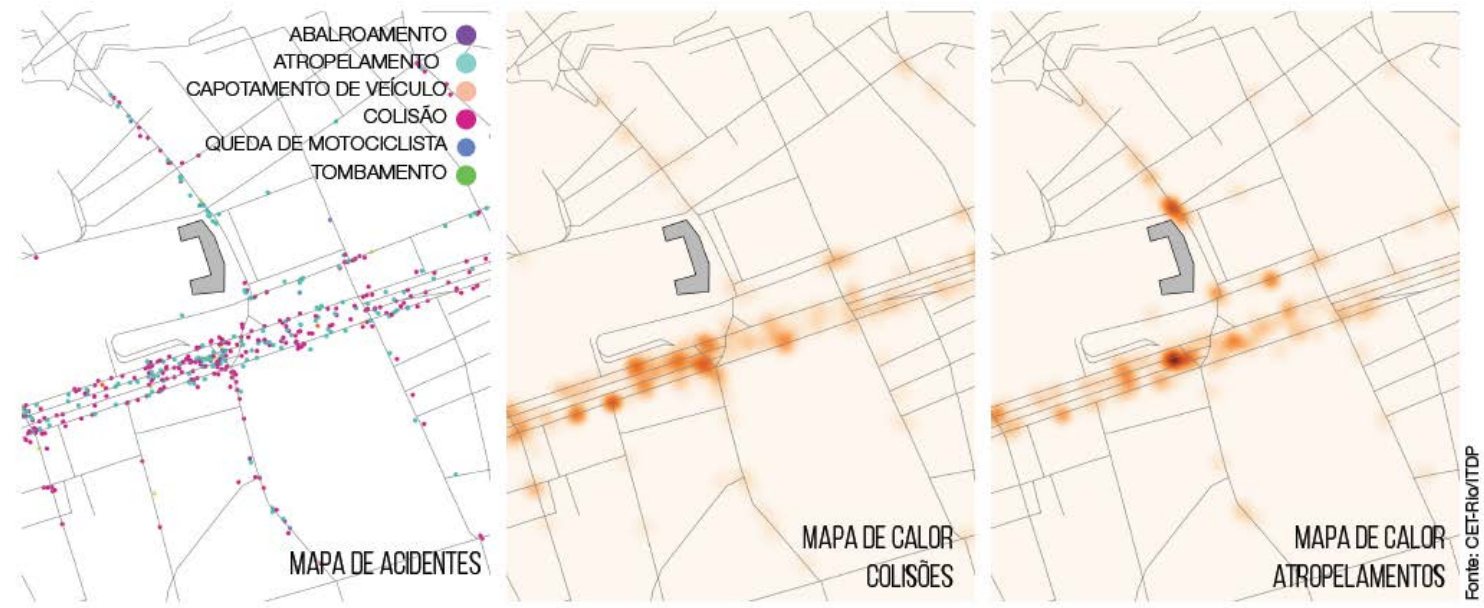

Imagem 14 - Mapas de segurança viária no entorno da estação Central do Brasil (CET-Rio/ITDP, 2016)

Para além do já relatado, a hostilidade ao pedestre na referida área se deve também à degradação, subutilização ou abandono de imóveis. Apesar do uso do solo diversificado, a falta de utilização de alguns imóveis e a desconexão com a realidade dos fluxos dos pedestres, acaba por gerar uma sensação de insegurança e de fato, aumenta os índices de violência urbana, comprovada com base nos dados do Sistema de Informação sobre Mortalidade (SIM, 2016), em que a AP1 - área de planejamento do Município do Rio de Janeiro delimitada no Plano Diretor da cidade que à que este artigo se refere - figura primeiro lugar no ranking, tanto em mortalidade por causas externas, quanto por homicídios.

Dessa forma, não só pela conclusão acerca dos dados apresentados, mas, principalmente, a partir da observação da área pela equipe, em que foram detectados diversos pontos problemáticos- a serem listado a seguir -, é que se confirma a hipótese levantada: a real falta de qualidade no espaço urbano tangível ao pedestre, dando então margem para uma proposição de estratégias de melhoria do ambiente urbano. 


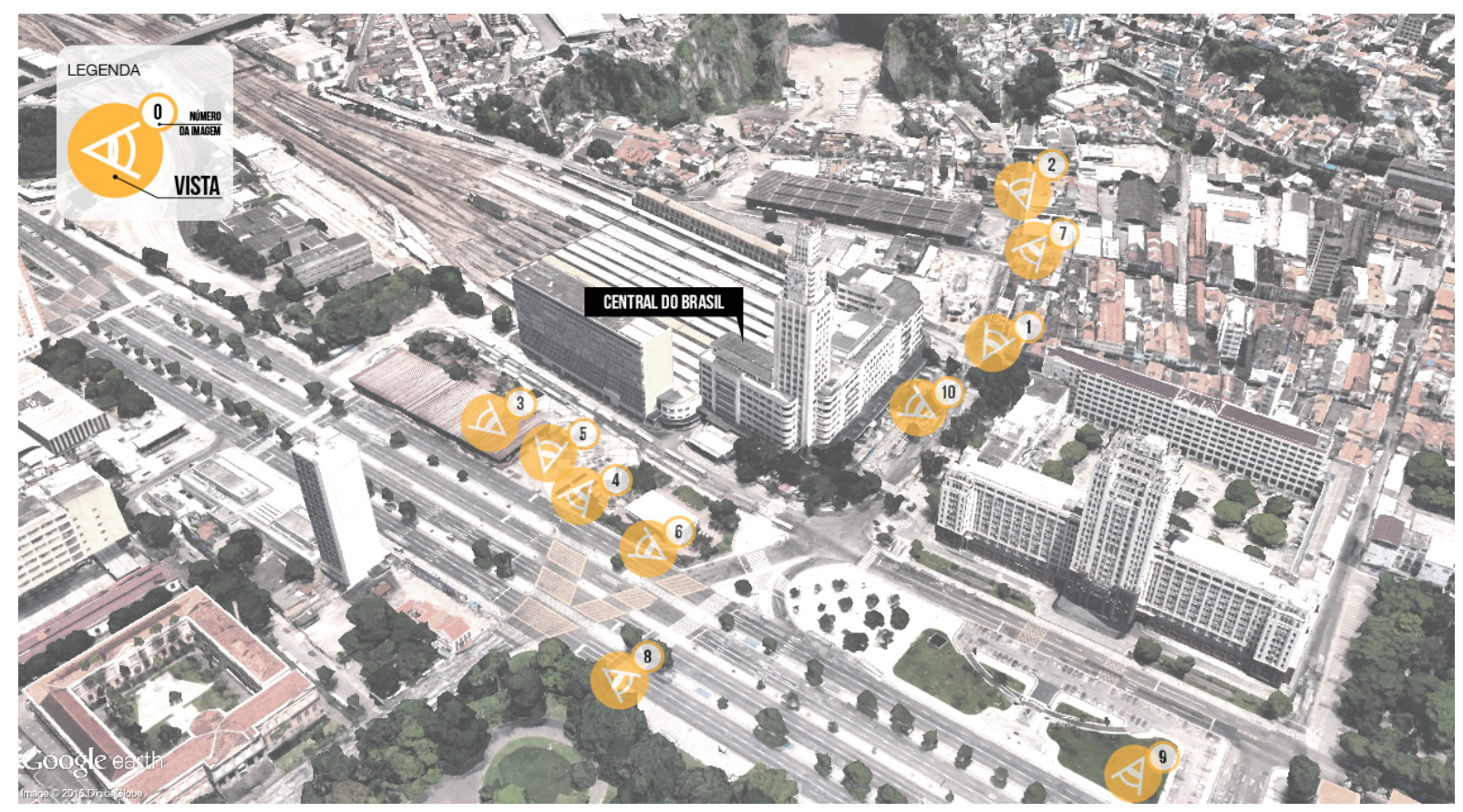

Imagem 15 - Mapas de visuais do levantamento fotográfico Elaboração própria

\section{PERCEPCW̃̃ES DO ESPAC̣O}

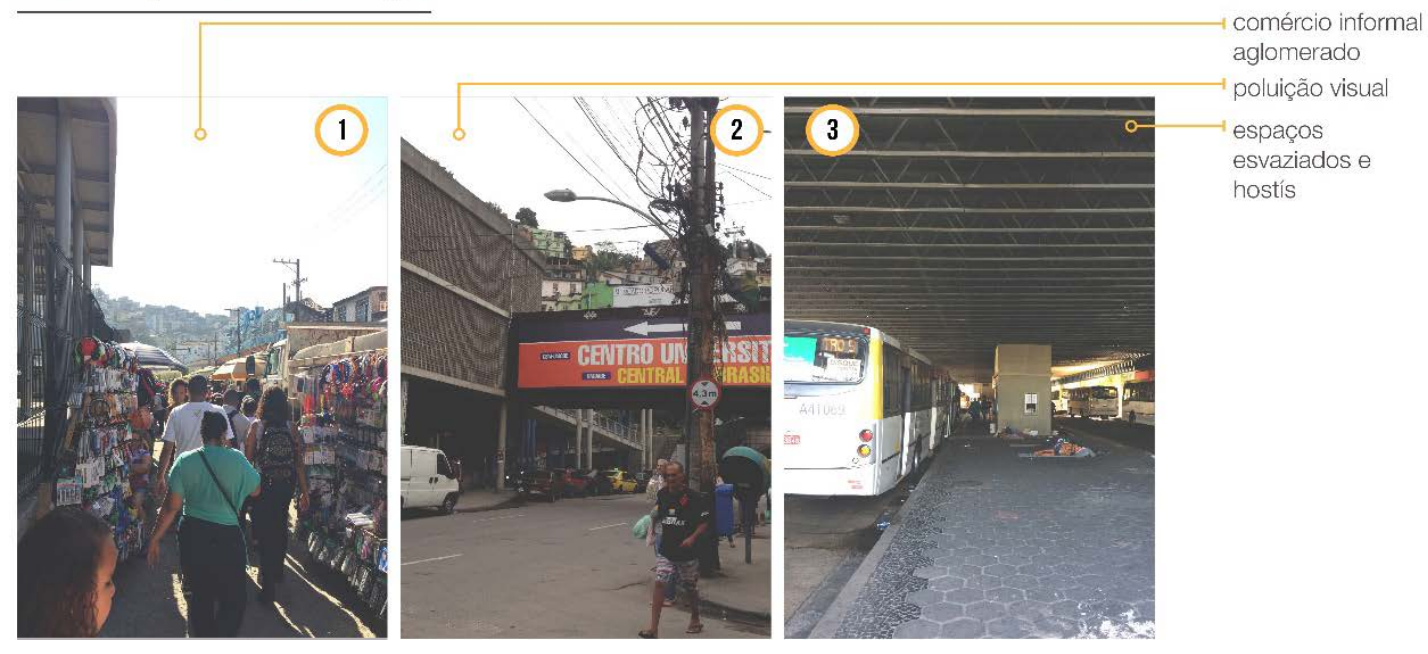




\section{DESCONECTIVIDADE}

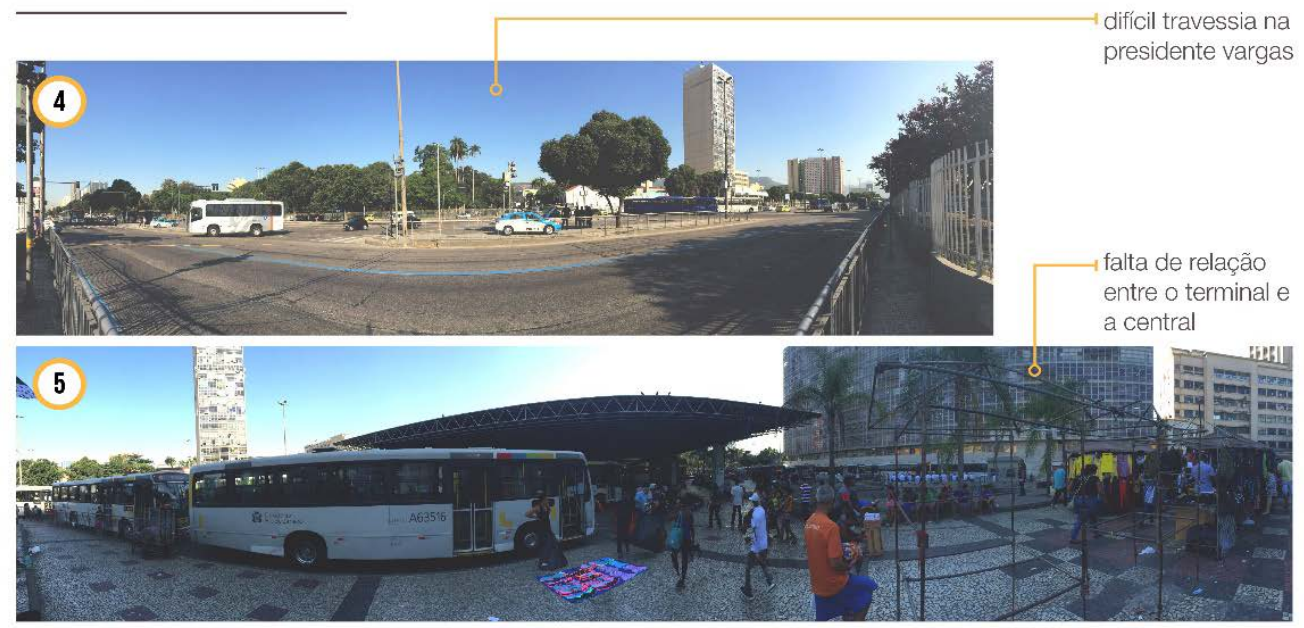

\section{CONDIÇÃO DO PEDESTRE}

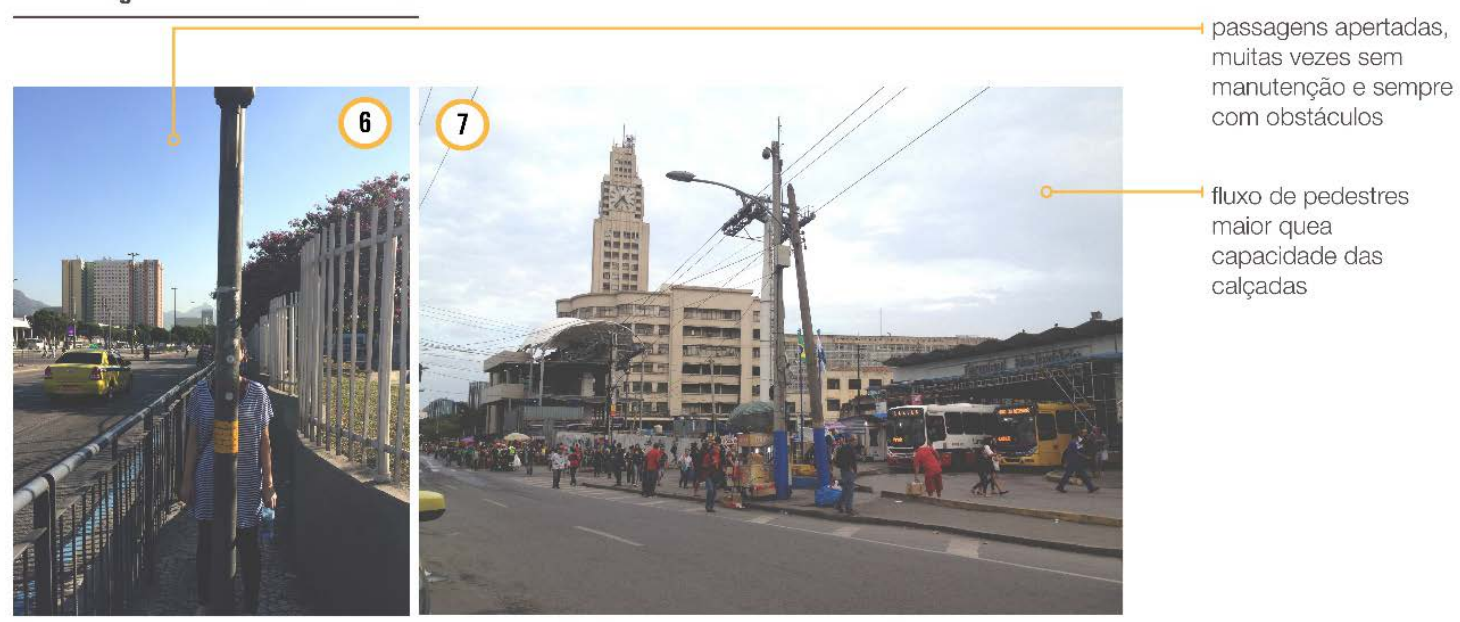

\section{UNIDADE VISUAL}
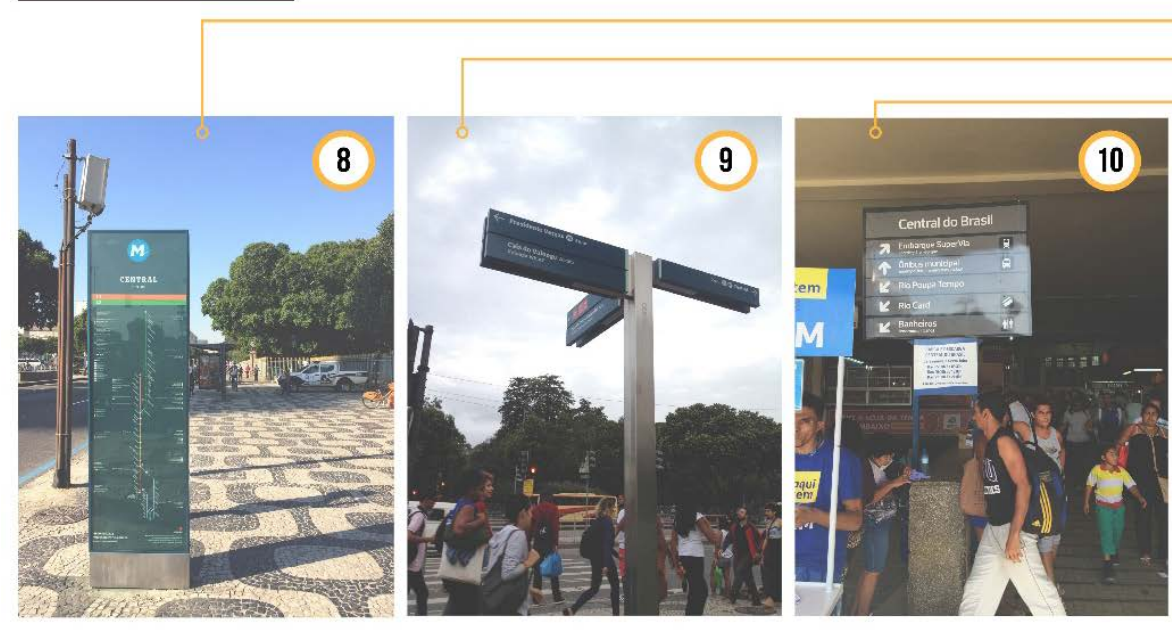

metro + rio ape

rio ape

${ }^{-}$central + supervia

Levantamento fotográfico

Elaboração própria 
Numa apreensão geral do espaço, nota-se o estrangulamento das calçadas pelo comércio informal desorganizado; desordem na implantação de infraestruturas nos passeios gerando obstáculos na passagem; desacordo no dimensionamento dos passeios em relação ao intenso fluxo de pessoas na região; áreas de difícil travessia; falta de interligação e identidade entre a estação principal e os terminais de ônibus adjacentes; ausência de unidade na linguagem visual dos diversos modais presentes. Em suma, o pedestre figura num ambiente desconexo, agressivo e confuso.

\section{PROPOSTAS}

Ao transitar nos arredores da estação Central do Brasil, instintivamente percebe-se a carência na provisão de um espaço público convidativo às pessoas que ali circulam diariamente em busca da grande oferta de transporte público presente. Ademais, a região tratada neste artigo não só é caracterizada pela ausência de um desenho urbano voltado ao transporte ativo em geral, como representa uma área hostil à população.

Este trabalho vem com a pretensão de sugerir alternativas e soluções que possibilitem uma profunda inversão da lógica atual da área estudada. Sendo assim, toma-se então o pedestre como módulo base da mobilidade urbana sustentável, em que todo e qualquer usuário desempenha a função de caminhar, independente de qual será a sua escolha final como meio de deslocamento. Para tanto, foram lançadas algumas estratégias de intervenção baseadas nos 'Dez Passos da Caminhabilidade' trazidos por Jeff Speck no livro 'Cidade Caminhável'. Segundo o SPECK (2016), a caminhada deve ser proveitosa, segura, confortável e interessante. Para isso é necessário "Passo 1: pôr o automóvel em seu lugar; Passo 2: Mesclar os usos; Passo 3: Adequar o estacionamento; Passo 4: Deixar o sistema de transporte fluir; Passo 5: Proteger o pedestre; Passo 6: Acolher as bicicletas; Passo 7: Criar bons espaços; Passo 8: Plantar árvores; Passo 9: Criar faces de ruas agradáveis e singulares; Passo 10: Eleger suas prioridades".

Levou-se também em consideração os princípios para o Desenvolvimento Orientado ao Transporte Público e Não Motorizado (TOD) ${ }^{5}$, entretanto, para alavancar o ganho no tecido urbano nesse sentido, a Central do Brasil e suas imediações devem ser observadas não só sob a ótica do desenvolvimento adjacente à um modal de transporte $(T A D)^{6}$, "em que o foco principal é a proximidade física, com o simples objetivo de capturar o valor da terra"7 (RENNE apud VALE, 2015: 70, tradução própria), e sim com intuito de transformá-la num espaço equitativo, seguro e também legitimo aos pedestres e ciclistas. "Dentre outras características, como variedade, complexidade e segurança, a escala humana tem sido vista como ponto chave de um TOD, o que é claramente associado ao ambiente caminhável" ${ }^{8}$ (JACOBSON e FORSYTH apud VALE, 2015: 72, tradução própria).

Pela contextualização geográfica e conformação sócio-espacial previamente descritas, fez-se também a análise in-loco das características do entorno da estação pela equipe, em primeira instância, a fim de construir o cenário problemático encontrado. Obteve-se a constatação, com base no fluxo intenso de pedestres, acercada concreta necessidade de direcionar as propostas à esses atores - os menos privilegiados na trama urbana abordada. O trabalho visa propor medidas para reorganizar tais fluxos, criar espaços mais agradáveis e caminhos mais seguros para os pedestres na troca entre modais, como alternativas para valorizar e revitalizar a permanência tanto quanto o deslocamento e fazer com que cada vez mais as pessoas optem pelo transporte público em detrimento do transporte individual motorizado.

\footnotetext{
${ }^{5}$ TransportOrientedDevelopment

${ }^{6}$ Transport-AdjacentDevelopment

${ }^{7}$ "Indeed, there is a clear distinction between a TOD and a transit-adjacent development (TAD) approach, in which them a infocusis physical proximity, with a simple objective of capturing the value of the land adjacent to the transit stop, not necessarily with a pedestrian friendly built environment and a functional connectivity between land uses and the transit stop [...]"

8"Among other important urban design features like variety, complexity and safety, a human scale design is being pointed as a keyfeature of a TOD, which is clearly associated with a walkable environment."
} 
Em linhas gerais, aposta-se no adensamento da área vinculado ao uso misto, e revisão dos usos incompatíveis, com auxílio das políticas públicas e territoriais na área; na revitalização de imóveis subutilizados; na remodelação dos terminais rodoviários, de maneira a se tornarem conexos com o saguão da estação principal e proporcionar integração visual; na implantação de ciclovias e travessias em nível; e finalmente, na instauração da redução de velocidade em trechos específicos para a acalmia no tráfego.

Foram indicadas mudanças pontuais em dois trechos específicos, sendo um na Avenida Presidente Vargas, que separa a Central do Brasil do Campo de Santana - parque municipal que aqui configura um ponto de atratividade no projeto, num desenho urbano visivelmente direcionado aos carros particulares, e o outro na Rua Bento Ribeiro, de escala menor, congestionada e não menos desordenada aos usuários que a primeira. Para Avenida Presidente Vargas, propõe-se a relocação de travessias e nivelamento das mesmas ao passeio para priorizar e acalmar o trânsito de carros, aliando o tempo semafórico com a real necessidade de cruzamento das pessoas; além, implantação de ciclovias segregadas em acordo com prévio planejamento sugerido pelo programa Ciclo-rotas, juntamente com a redução de velocidade de circulação nas faixas principais pra $50 \mathrm{~km} / \mathrm{h}$ e nas vias marginais de $40 \mathrm{~km} / \mathrm{h}$. Já na Bento Ribeiro, almejou-se uma escala mais intimista ao nível dos olhos, com o incentivo ao uso misto - do aumento do gabarito das edificações à redivisão de lotes - e fachadas ativas, implantação de uso compartilhado da via - com velocidade máxima permitida de $30 \mathrm{~km} / \mathrm{h}$-, entre pedestres, ciclistas, ônibus BRT e Veículo Leve sob trilhos, com a supressão do uso do automóvel, onde o mobiliário urbano, a iluminação, o comércio de rua e até a pavimentação em nível têm o intuito de valorizar a caminhada.

Buscando recolocar o pedestre no centro da discussão e dar a ele novamente a possibilidade de usufruir do espaço público de forma segura e com qualidade, tais recursos direcionam o planejamento à um olhar mais cauteloso em relação à formação social do espaço urbano, considerando não mais só um modal - como no planejamento modernista -, mas fazendo jus à cidade contemporânea e proporcionando um uso equilibrado, diverso, por todos os entes da sociedade.

Além do já exposto, uma das premissas mais importantes para a revitalização da região, foi a criação de espaços públicos de lazer, que servissem tanto aos atuais como aos futuros residentes da área e aos transeuntes, criando um atrativo para 'estar', além de ser uma forma de atrair novas pessoas para a área nos finais de semana e em horários não comerciais. Foram identificados, portanto, os parques, praças e espaços públicos de lazer já existentes e então propostas medidas para revitalizá-los. O Campo de Santana, como já foi dito, tem sido nos últimos anos um enclave na malha urbana. Apesar da sua beleza e valor histórico é um espaço pouco utilizado, gradeado e fechado ao público durante a noite. Com a finalidade de reinserir esse espaço na rota natural das pessoas que andam pela área todos os dias e de torná-lo novamente atrativo à todas as classes que anseiam por um espaço de lazer no centro da cidade, como medida inicial, retira-se a grade que o separa do passeio e intimida os usuários e propõe serviços no seu interior, o que evita a monotonia e mais uma vez, a sensação de insegurança. 
AV. PRES. VARGAS

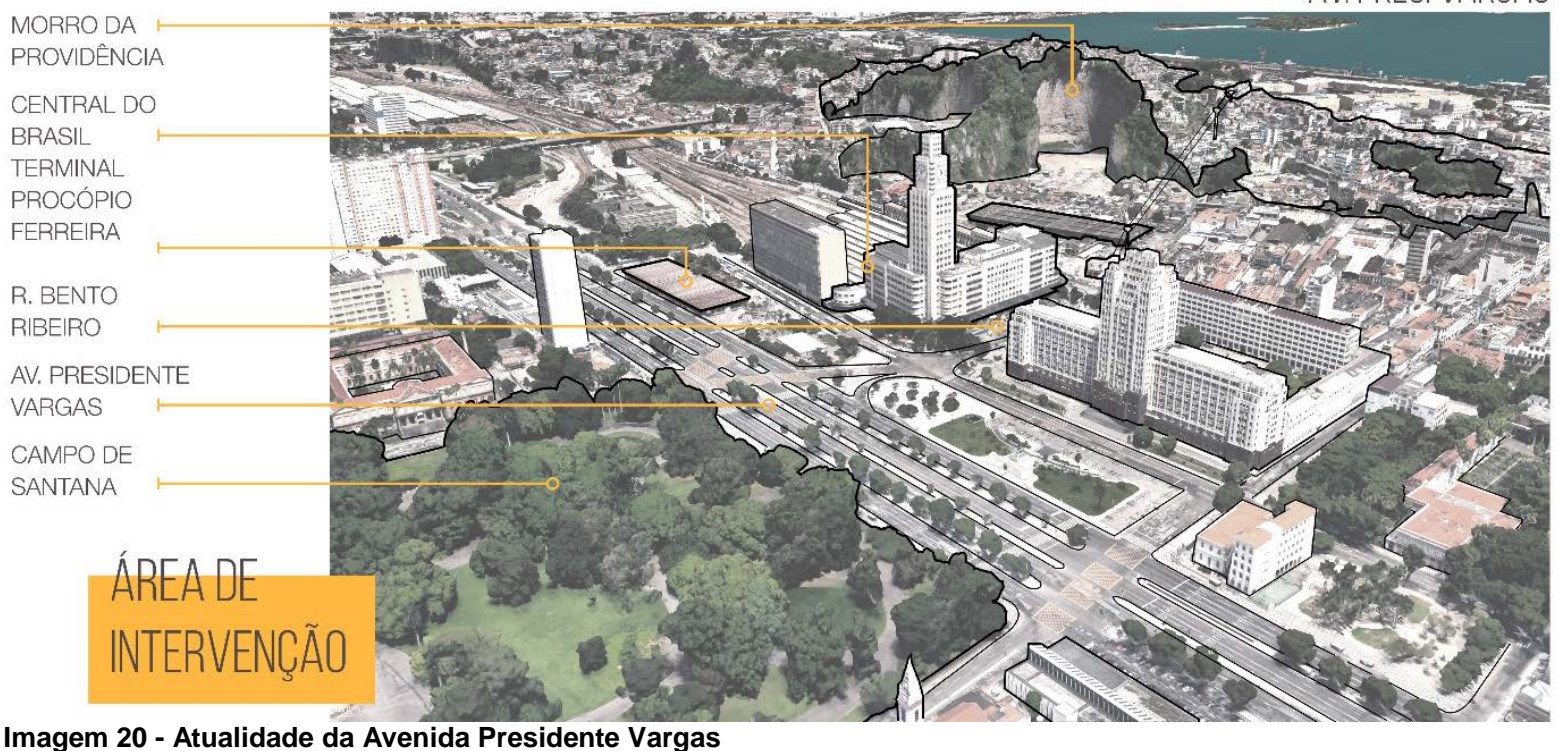

Imagem 20 - Atualidade da Avenida Presidente Vargas Elaboração prória.

AV. PRES. VARGAS

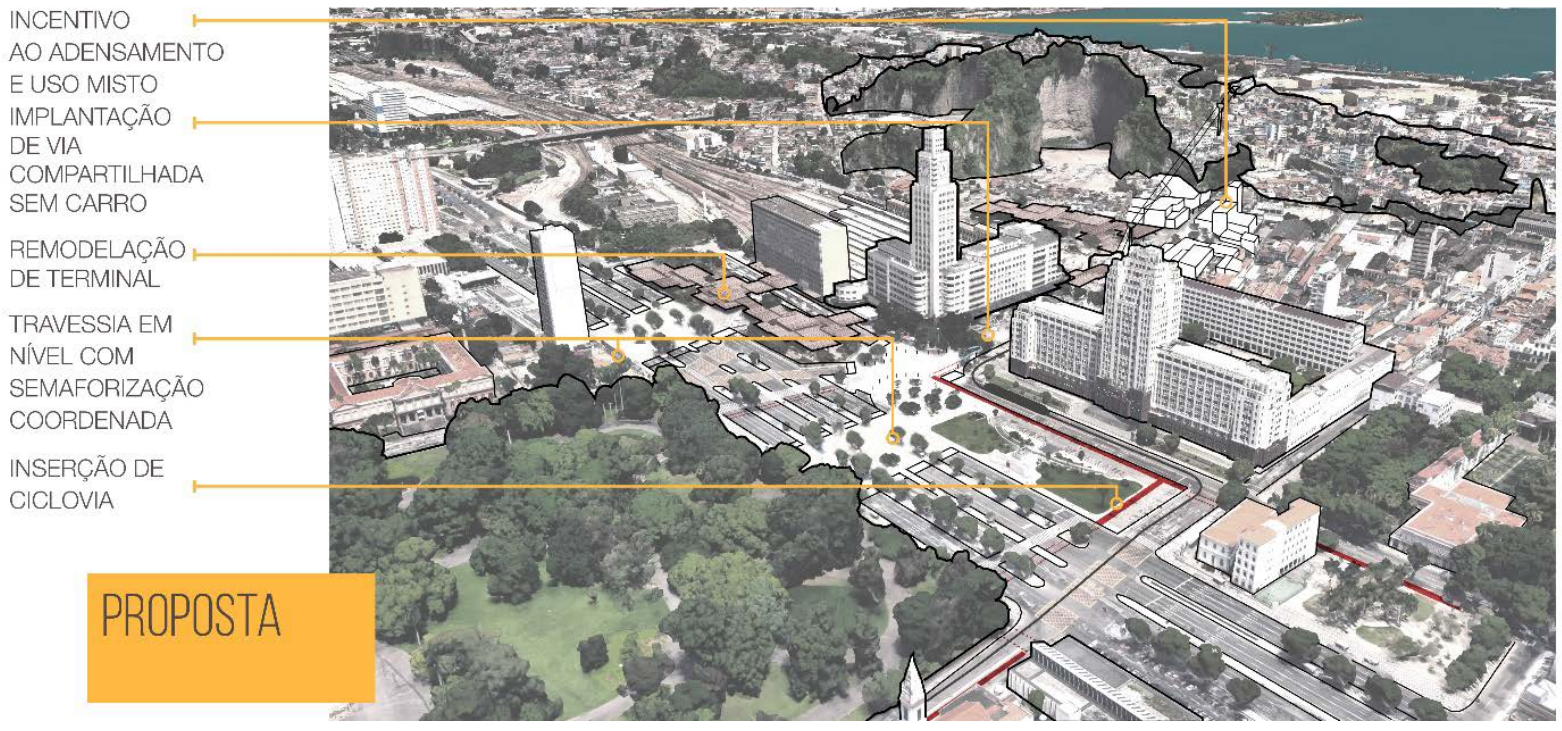

Imagem 21 - Proposta para a Avenida Presidente Vargas

Elaboração prória. 


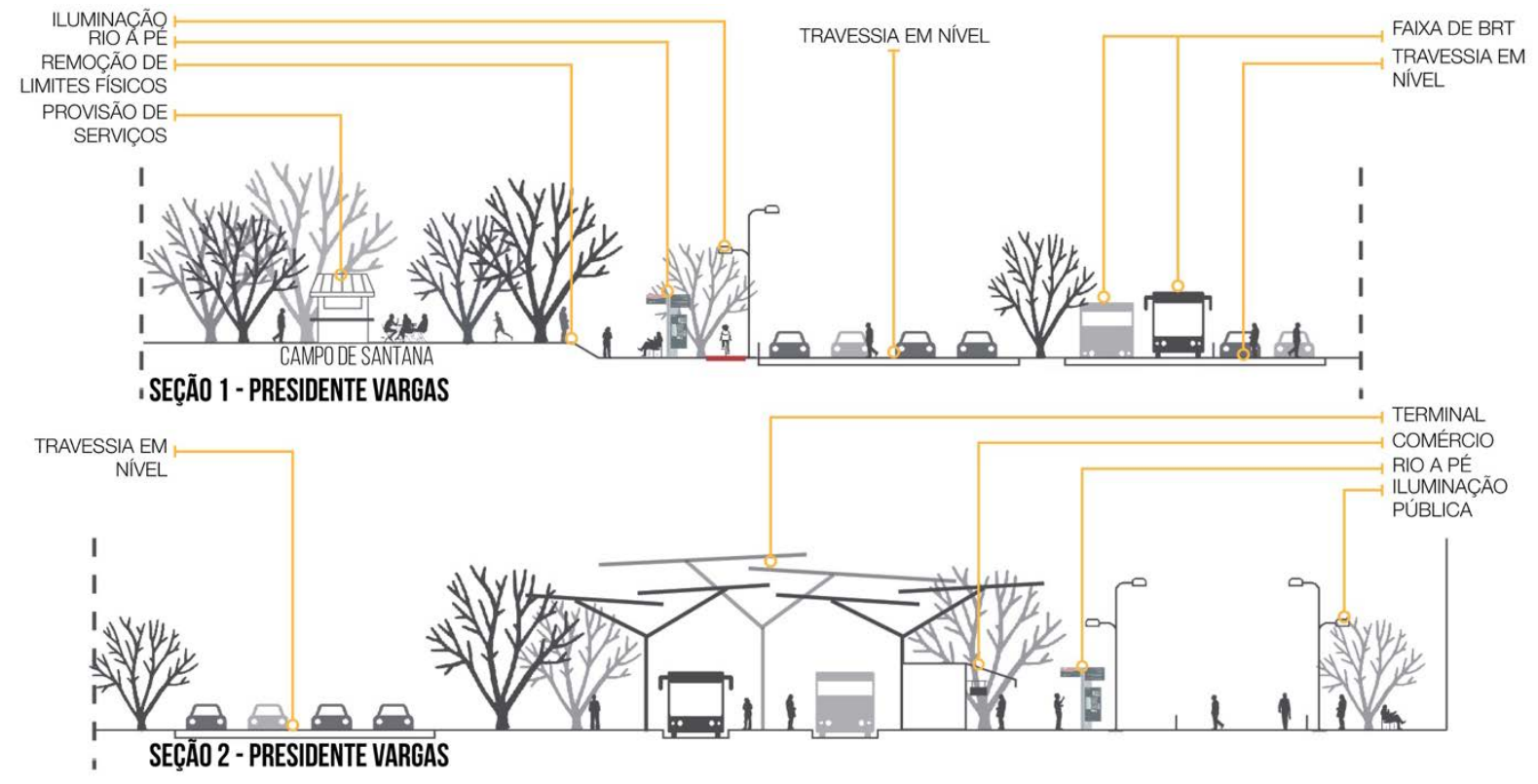

Imagem 22 - Seções propostas para a Avenida Presidente Vargas

Elaboração própria.

R. BENTO RIBEIRO

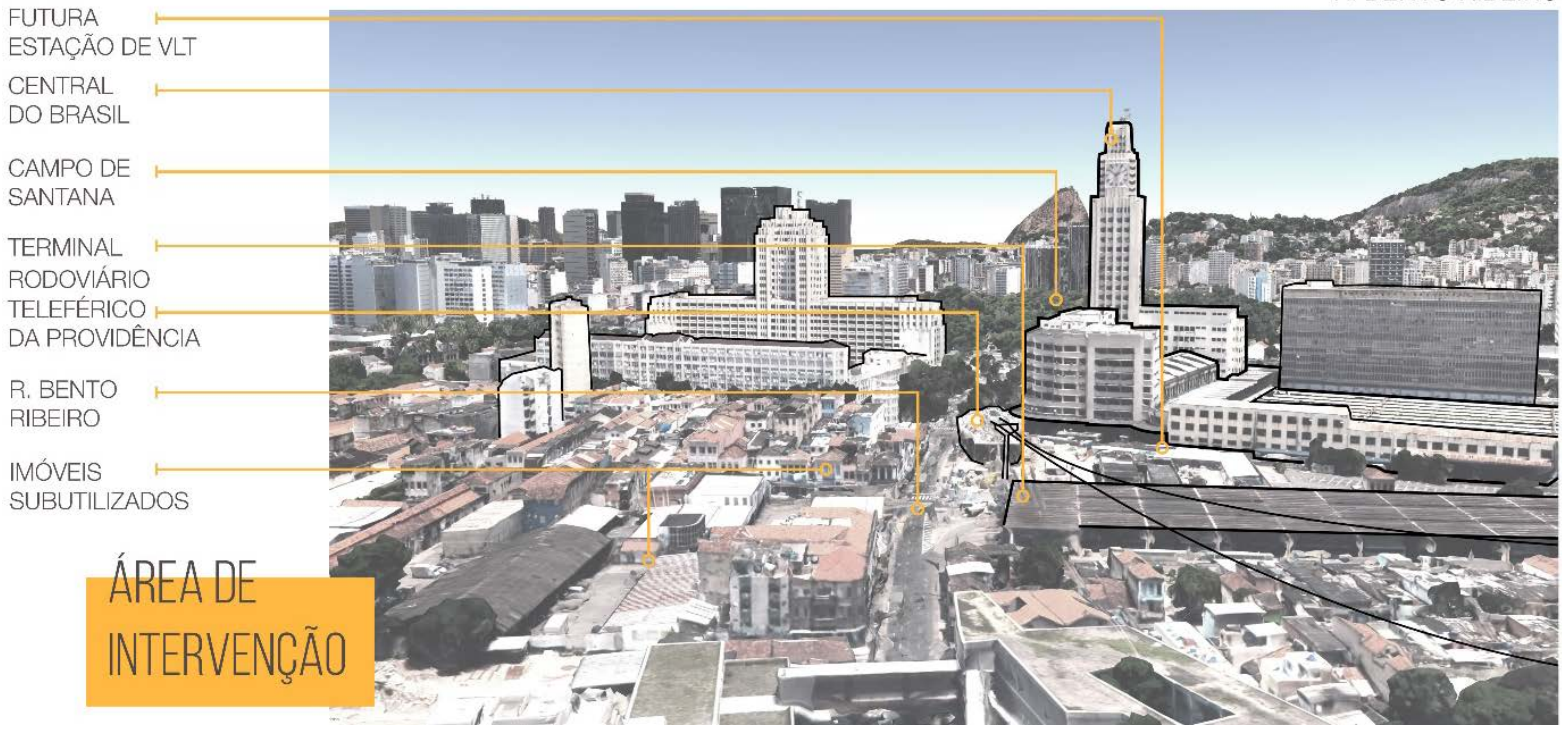

Imagem 23 - Atualidade da Rua Bento Ribeiro

Elaboração própria. 


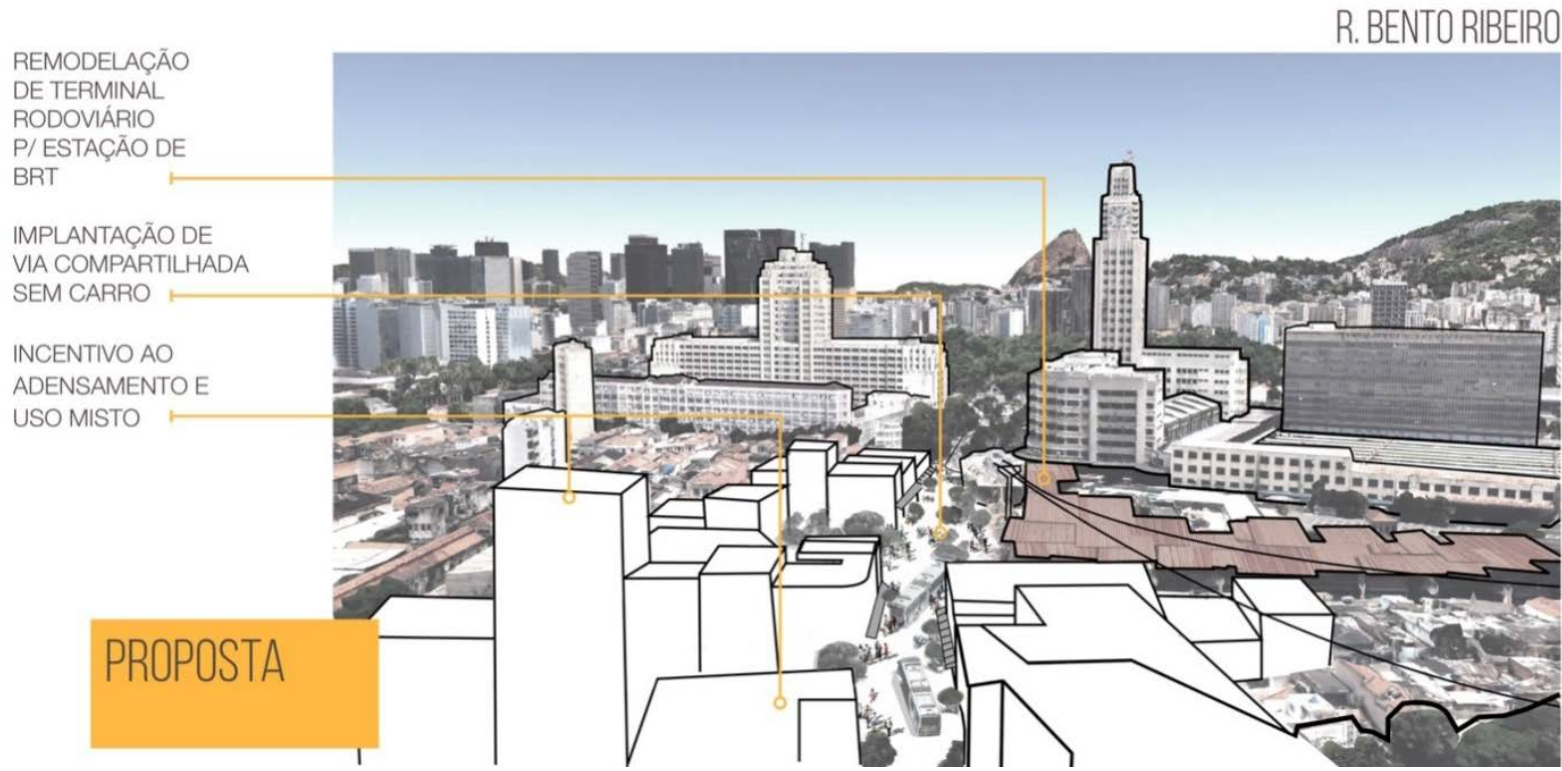

Imagem 24 - Proposta geral para a Rua Bento Ribeiro Elaboração própria.
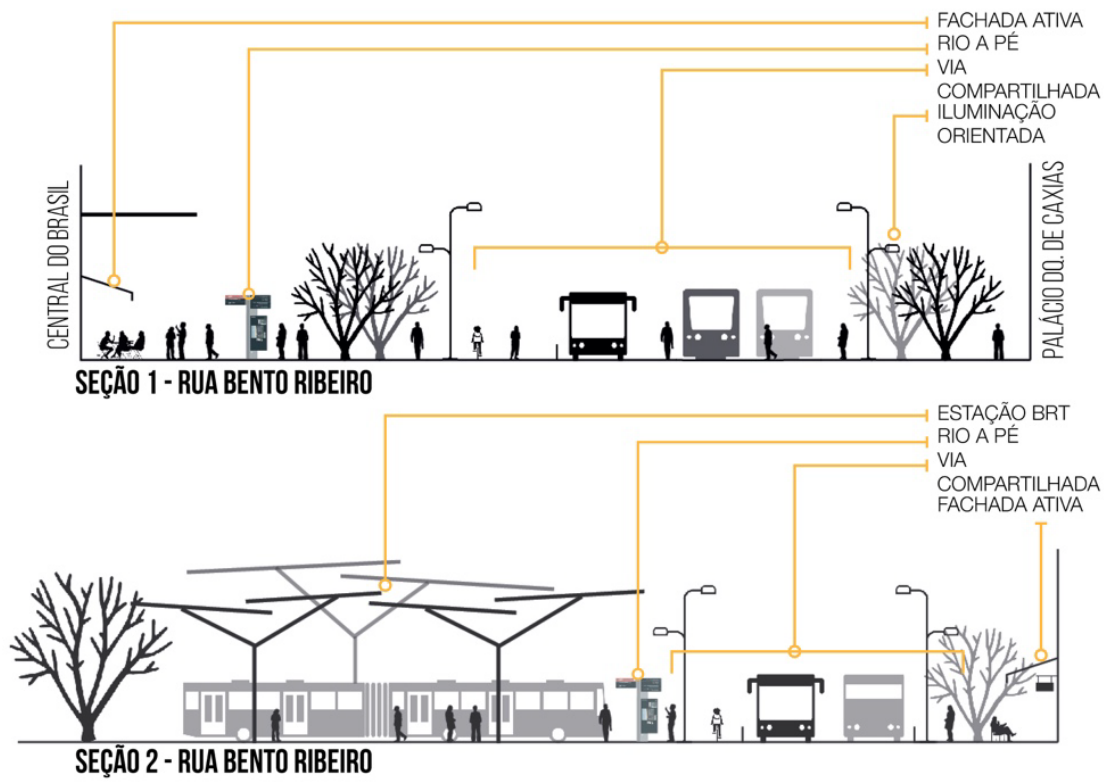

Imagem 25 - Seções propostas para a Rua Bento Ribeiro

Elaboração própria.

Com a recuperação da vitalidade, por fim pretendida, a área passará a ter movimento e atratividade, influenciando positivamente a economia local, fato que permitirá aos residentes e visitantes dispor de uma série de serviços dentro de um raio de caminhada aceitável. Consequentemente haverá uma redução na sensação de insegurança, uma vez que, com usuários transitando ininterruptamente, atrairá ainda mais pessoas a observar o espaço, teoria muito bem defendida por JACOBS (2011) ao comparar a segurança pública aos olhos da rua. Portanto, a "vitalidade no espaço público urbano é relativa à um espaço seguro, desejável, e mais atrativo que apresenta a capacidade de oferecer mais chances para atividades sociais tanto quanto ser um lugar para trocas culturais. Esse tipo de espaço 
é um resultado vitorioso no processo de construir lugares para pessoas. ${ }^{9}$ (JALALADDINI e OKTAY, 2011: 665, tradução própria).

\section{CONSIDERAÇÕES FINAIS}

Vimos, ao longo deste breve estudo, os conceitos de rua como um lugar, cidade para se caminhar e para permanecer, elucidados por Jan Gehl e Jeff Speck e, ainda, a concepção de um nó de transportes e sua importância, tanto para o bom funcionamento da rede de transportes de uma cidade, como na representação de uma centralidade. Porém, constatou-se que, como na hipótese que alavancou este trabalho, apesar dos vários potenciais para o bem, a realidade apresentada pelo espaço, tanto físico quanto urbano, da Central do Brasil não é muito condizente com tais ideias e ideais.

Representando também um "Polo Gerador de Viagens", como visto no item 2 deste artigo, a Central do Brasil tem o poder de aglomerar um grande número de transeuntes durante o dia, seja para passagem ou baldeação entre modais de transporte, seja para uso do espaço e serviços presentes. Esse valor e potencial de reunir pessoas traz a responsabilidade da oferta de um ambiente acessível e voltado para o usuário, um ambiente amigável e convidativo, prático e seguro, um lugar com características que permeiam as cidades caminháveis.

O estudo do histórico, tanto da Cidade quanto de sua área central, teve grande serventia na ilustração e compreensão dos valores exercidos pelo nó modal e sua área de entorno, o que proporcionou o começo da análise da formação e realidade do espaço edificado oferecido aos usuários. O levantamento fotográfico advindo da imersão ao ambiente estudado trouxe, por fim, à tona as dificuldades passadas diariamente pelos transeuntes utilizadores da Central, gerando assim combustível para que as propostas de melhoria do espaço focem tecidas.

Como mostrado, o objetivo primordial deste artigo era abordar o quadro atual da realidade do pedestre e usuário da Central do Brasil, o nó de transportes da cidade do Rio de Janeiro, assim como trazer as propostas elaboradas pelo grupo para a melhoria do espaço a nível do usuário. Consideramos então, que dados os objetivos iniciais deste trabalho, o processo foi muito proveitoso e alcançou o propósito de reconhecimento e vivência do espaço pelo olhar e escala do pedestre.

${ }^{9}$ Vitality in urban public space refers to a safer, more desirable, and more attractive space which has the capacity for offering more choices for social activities as well as being a place for cultural exchanges. This kind of space is the successful result of the process of placemaking for people. 


\section{REFERÊNCIAS}

\section{Fontes Bibliográficas}

ABREU, Maurício de A. (2006). Evolução Urbana do Rio de Janeiro. Rio de Janeiro: Instituto Pereira Passos.

BHATTACHARYYAA, D. e MITRA, S. (2013). Making Siliguri a walkable city. Procedia - Social and Behavior al Sciences, 96, 2737-2744.

BRASIL, (2015). Ministério das cidades. Secretaria Nacional de Transporte e da Mobilidade Urbana, Caderno de referência para elaboração de plano de mobilidade urbana. Brasília: Semob.

DUARTE, Cristovão Fernandes. (2006). Forma e Movimento. Rio de Janeiro: Ed. PROURB.

GEHL, Jan. (2013). Cidade para Pessoas. São Paulo, Ed. Perspectiva.

HOLSTON, James. (1993). A cidade modernista: uma crítica de Brasília e sua utopia. São Paulo: Companhia das letras.

IBGE. (2010). Censo Demográfico. Disponível em: <http://www.censo2010.ibge.gov.br>

IBGE. (2015). Brasil em números. Disponível em: <http://biblioteca.ibge.gov.br/visualizacao/periodicos>

JACOBS, J. (2011). Morte e vida de grandes cidades. São Paulo: WMF Martins Fontes.

JALALADDINI, S. e OKTAY, D. (2012). Urban Public Spaces and Vitality: A Socio-Spatial Analysis in the Streets of Cypriot Towns. Procedia - Social and Behavior al Sciences, 35, 664-674.

KNEIB, E. C. (2012). Polos geradores de viagens, centralidades e seus impactos na mobilidade urbana. Periódico // Pluris.

MINISTÉRIO DAS CIDADES. (2006). Brasil Acessível: Programa brasileiro de Mobilidade Urbana. Brasília.

MOVAHED, S., AZADI, S., e ZAKERI, H. (2012). A Safe Pedestrian Walkway; Creation a Safe Public Space Based on Pedestrian Safety. Procedia - Social and Behavior al Sciences, 35, 572-585.

OBSERVATÓRIO DAS METRÓPOLES. (2015). Transformações na ordem Urbana. Rio de Janeiro.

ROGERS, Richard. (2013). Cidades para um pequeno planeta. Londres: Faber and Faber Limited.

SANTOS, Denise Vaz de Carvalho e FREITAS, Ilce Marilia Dantas Pinto de Medidas de Mobilidade Urbana Sustentável (2014): Propostas para o licenciamento de Polos Geradores De Viagens. Periódico // TRANSPORTES.

SISSON, Rachel. (2008). Espaço e Poder - Os três centros do Rio de Janeiro. Rio de Janeiro: Arco Produções.

SPECK, J. (2016). Cidade Caminhável. São Paulo: Perspectiva.

VALE, D. (2015). Transit-oriented development, integration of land use and transport, and pedestrian accessibility: Combining node-place model with pedestrian shed ratio to evaluate and classify station areas in Lisbon. Journal of Transport Geography, 45, 70-80.

\section{Fontes eletrônicas}

http://ta.org.br/site/news/crc.pdf (Consulta em: 09/07/2016)

http://imaginerio.org (Consulta em: 09/07/2016)

http://maps.google.com (Consulta em: 13/07/2016)

http://www.portomaravilha.com.br/noticiasdetalhe/4126 (Consulta em: 13/07/2016) 